\title{
The Artinskian Siderópolis Member macroflora, Rio Bonito Formation and its stratigraphical correlation with other early Permian macrofloras of Paraná Basin, Brazil
}

\author{
A macroflora artinskiana do Membro Siderópolis, Formação Rio Bonito e sua correlação \\ estratigráfica com outras eopermianas da Bacia do Paraná, Brasil
}

\author{
Mary Elizabeth Cerruti Bernardes-de-Oliveira1', Sandra Eiko Mune1, Maria Judite Garcia1, Roberto lannuzzi², \\ Margot Guerra-Sommer ${ }^{2}$, André Jasper ${ }^{3}$, Pauline Sabina Kavali ${ }^{1,4}$, Mahesh Shivanna ${ }^{2}$ and \\ Karoline Gonçalves Pereira ${ }^{5}$ \\ 1 Universidade de São Paulo - USP, Laboratório de Paleobotânica e Palinologia, Instituto de Geociências, \\ Departamento de Geologia Sedimentar e Ambiental - GSA, Programa de Pós-graduação em Geoquímica e Geotectônica, \\ Rua do Lago, 562, CEP 05508-080, São Paulo, SP, Brazil (maryeliz@usp.br; smune@hotmail.com; mjudite@usp.br) \\ 2Universidade Federal do Rio Grande do Sul - UFRGS, Instituto de Geociências, Porto Alegre, RS, Brazil \\ (margot.sommer@ufrgs.br; roberto.iannuzzi@ufrgs.br; mahesh.shivanna@ufrgs.br) \\ ${ }^{3}$ Centro Universitário UNIVATES, Lageado, RS, Brazil (ajasper@univates.br) \\ 4Birbal Sahni Institute of Palaeosciences, Lucknow, India (paulinesabina@gmail.com) \\ 5Universidade Guarulhos - UnG, Guarulhos, SP, Brazil (karolthgermany@gmail.com)
}

Received on April $1^{\text {st }}, 2016$; accepted on October 10 $10^{\text {th }}, 2016$

\begin{abstract}
An overview of the composition of the paleoflora preserved in clay-siltstones of the Siderópolis Member, Rio Bonito Formation is presented in order to establish phytostratigraphical comparisons with other Late Pennsylvanian and Cisuralian paleofloras of the Paraná Basin. The Rio Bonito Formation, the most important of the coal bearing lithostratigraphic units of the Paraná Basin belongs to the Gondwana I Supersequence (Pennsylvanian-Early Triassic). The Siderópolis paleoflora occurs in the uppermost layers of coal of Rio Bonito Formation in Santa Catarina coalfield in four distinct localities of the State of Santa Catarina: Lauro Muller, Criciúma, São Marcos and Treviso. In this paleoflora the glossopterid leaves predominate with an evident dominance of the genus Glossopteris over Gangamopteris, followed by Cordaitalean leaves (Noeggerathiopsis) and seeds (Cordaicarpus, Samaropsis, Cornucarpus). Sterile fronds are common and few are fertile (Sphenopteris, Pecopteris, Ponsotheca and Notoangaridium). Pteridosperm reproductive structures (Arberia, Arberiopsis, Ottokaria) are not frequent and branches of conifers (Brasilocladus, Buriadia) are rare. Concerning other paleofloras of the basin, the Siderópolis paleoflora is distinguished by high diversity and many exclusive taxa showing only few similarities with some paleofloras registered in Rio Grande do Sul, occurring in outcrops of the Rio Bonito Formation such as Morro do Papaléo (upper section) and Quitéria. The differences may reflect an upper stratigraphic position, but may also indicate differences in sedimentation and / or in paleoecological conditions.
\end{abstract}

Keywords: Glossopteris; Gondwanan Flora; Artinskian.

\section{Resumo}

Apresenta-se aqui uma síntese da composição da paleoflora preservada em siltitos argilosos do Membro Siderópolis, Formação Rio Bonito tendo como objetivo estabelecer comparações fitoestratigráficas com outras paleofloras neopensilvanianas e cisuralianas da Bacia do Paraná. A Formação Rio Bonito, a mais importante das unidades litoestratigráficas portadoras de carvão da Bacia do Paraná, pertence à supersequência Gondwana I (Pensilvaniano-Eotriássico). A paleoflora Siderópolis ocorre nas camadas de carvão mais superiores da Formação Rio Bonito na região carvoeira de Santa Catarina, em quatro áreas distintas do Estado de Santa Catarina: Lauro Muller, Criciúma, São Marcos e Treviso. Na paleoflora, as folhas de glossopterídeas predominam com um evidente domínio do gênero Glossopteris sobre Gangamopteris, seguido por folhas cordaitaleanas (Noeggerathiopsis) e sementes (Cordaicarpus, Samaropsis, Cornucarpus). Frondes estéreis são comuns havendo poucas férteis (Sphenopteris, Pecopteris, Ponsotheca, Notoangaridium). Estruturas reprodutivas pteridospérmicas 
(Arberia, Arberiopsis, Ottokaria) e ramos de coníferas (Brasilocladus, Buriadia) são raros. Em relação a outras paleofloras da bacia, a de Siderópolis distingue-se por apresentar diversidade mais alta e muitos táxons exclusivos mostrando apenas umas poucas semelhanças com algumas paleofloras registradas no Rio Grande do Sul, ocorrendo em afloramentos do Rio Bonito tais como Morro do Papaléo (porção superior) e Quitéria. Essas diferenças podem refletir uma posição estratigráfica superior, mas pode também indicar diferenças em condições de sedimentação e / ou paleoecológicas.

Palavras-chave: Glossopteris; Flora Gondvânica; Artinskiano.

\section{INTRODUCTION}

The geological and biological data obtained for the lower Permian Brazilian coal basins (in Paraná Basin) have led to the conclusion that tectonic and environmental conditions, as well as the peat forming plant communities were important factors that influenced the formation and characterization of coal deposits (Mendonça Filho et al., 2013).

The available paleobotanical literature on the coal roof shale floras in Paraná Basin, although very extensive, has encompassed mainly the coalfields of the State of Rio Grande do Sul (Guerra-Sommer et al., 1984; Cazzulo-Klepzig et al., 2005, 2007; Guerra-Sommer et al., 2008; Iannuzzi, 2010; Simas et al., 2012, 2013). On the contrary, there is relatively few data for the nearby Santa Catarina Coalfield (Machado, 1972; Bortoluzzi et al., 1978; Bernardes de Oliveira, 1980a).

Palynofacies, palynological and paleobotanical analyses on the Bonito coal seam in the region of Lauro Müller developed by Mendonça Filho et al. (2013), indicated changes in palaeoecological conditions that have favored the development of different plant communities during the depositional time span from a forested gymnosperm at the base to a lycophytes (Brasilodendron type), subarborescent plant dominated scenario at the top.

The paleoflora of the Siderópolis Member has been described for distinct areas in the State of Santa Catarina by different authors as shown below. This paleoflora has been considered as Artinskian and stand out as the most typical and diversified postglacial example of the Glossopteris flora associated with coal deposits found in the Lower Gondwana strata of the basin (Bernardes-de-Oliveira, 1980a; Iannuzzi, 2010). Nevertheless, the absence of correlative studies of this flora with other Gondwana floras has prevented major biostratigraphic, lithostratigraphic and paleogeographic considerations.

\section{GEOLOGIC AND STRATIGRAPHIC SETTINGS}

The Rio Bonito Formation, the most important coal bearing lithostratigraphic units of the Paraná Basin, belongs to the Gondwana I Supersequence (Pennsylvanian-Early Triassic) of Milani et al (1998). In the states of Santa Catarina and Paraná, Schneider et al. (1974) subdivided it into three members, designated from the base to the top as Triunfo Member (coastal and fluvial sandstones), Paraguaçu
Member (mudstones and fine grained marine sandstones) and Siderópolis Member (coastal and fluvial sandstones). Coal seams occur mostly in Triunfo Member, in the State of Paraná and in the Siderópolis Member in the State of Santa Catarina.

The "Catarinense coalfield" or the "Sul Catarinense coalfield" (Machado, 1972; Bortoluzzi et al., 1978 respectively), is an elongated polygonal basin of north-south direction, located in the southeastern portion of the State of Santa Catarina in an area of approximately $1.200 \mathrm{~km}^{2}$. The basin is comprised by portions of the Tubarão, Araranguá, Urussanga and Mampituba river basins, with $95 \mathrm{~km}$ length and an average of $20 \mathrm{~km}$ width, within an area delimited by coordinates $28^{\circ} 1^{\prime} \mathrm{S}$ to $29^{\circ} 30^{\prime} \mathrm{S}$ and $49^{\circ} 10^{\prime} \mathrm{W}$ to $49^{\circ} 37^{\prime} \mathrm{W}$.

From the base to the top, five major coal beds can be seen in the sedimentary sequence viz. Bonito, Ponte Alta, Irapuá, Barro Branco and Treviso (Putzer, 1952; Mendes, 1963), which belong to the Siderópolis Member and deposited mainly in coastal wetland environments, associated to coastal and deltaic deposits (Northfleet et al., 1969; Medeiros and Thomaz Filho, 1973) (Figure 1).

These coal seams were designated by Bortoluzzi et al. (1978), from the base to the top, as Pre-Bonito "C" and " $D$ ", Bonito, Ponte Alta, Irapuá "A", "B", and Barro Branco. The top Barro Branco coal seam which occurs throughout the basin has been extensively mined, whereas Irapuá, Ponte Alta and Bonito as well as the minor Pre-Bonito seams seem to be irregularly distributed in the basin and have been exploited either as open casts or gallery mines. Based on sequence stratigraphic method, but also taking into account paleontological and former lithostratigraphic criteria, Holz et al. (2010) concluded that the Rio Bonito succession in Paraná Basin included two third order sequences. In the State of Santa Catarina, the Siderópolis Member and almost all its coal seams are linked to the LPTS-4, of Artinskian age (Holz et al., 2010).

In the State of Rio Grande do Sul, the Rio Bonito Formation is not formally subdivided into different lithostratigraphic members and the coal seams are included in the underlying LPTS-3 and were deposited at the Sakmarian-Artinskian interval.

The coal palynofloras are included in the Protohaploxypinus goraiensis Subzone within the palynostratigraphic framework for the Brazilian Paraná Basin (Souza and Marques-Toigo, 2003). 


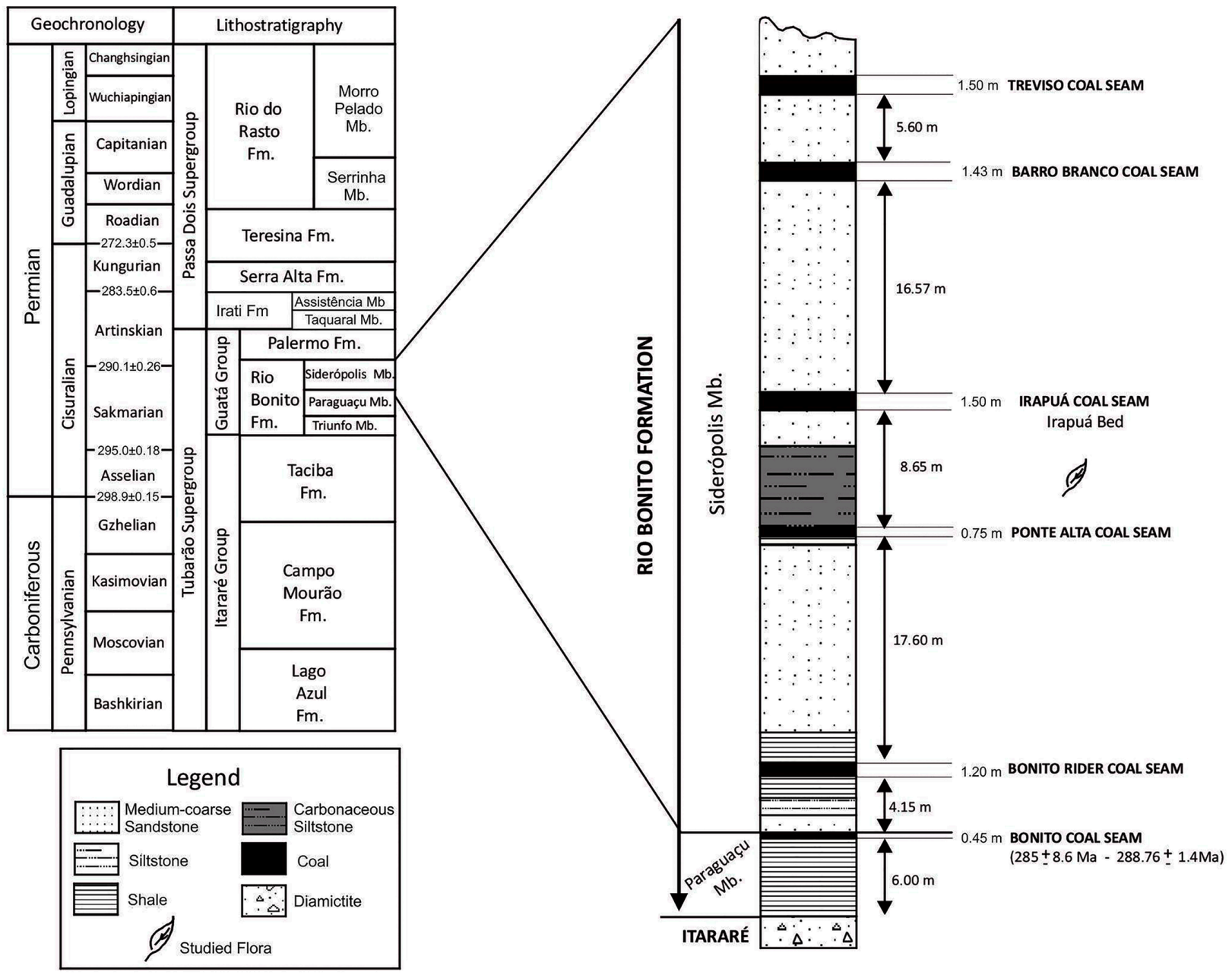

Figure 1. Siderópolis Member coal beds in Santa Catarina. Modified from lannuzzi (2010), based on data from Machado (1972) and Guerra-Sommer et al. (2008).

Formal relationships are also established with the Glossopteris-Rhodeopteridium Zone of Guerra-Sommer and Cazzulo-Klepzig (1993) within the phytostratigraphic chart for the lower Permian of southern Brazilian Paraná Basin (Iannuzzi, 2010).

\section{THE SIDERÓPOLIS MEMBER PALEOFLORA}

\section{Previous studies}

The Siderópolis Member paleoflora has its components registered in several taphofloras occurring in distinct areas of three municipalities of the State of Santa Catarina: Lauro Muller (Bonito and Barro Branco beds), Criciúma (Irapuá Bed) and Treviso (Treviso Bed) (Figure 2).

The first study of the Early Gondwanan Siderópolis Member paleoflora (then not yet so designated) was made by
D. White (1908a) based on material collected by I. C. White (1908b), recovered from fossiliferous horizons throughout all the "Rio Bonito Beds", in Lauro Muller (formerly known as Minas), in the northern portion of the Santa Catarina Coalfield (Figure 2).

Later, Rigby (1972a) presented a list of phytofossil components based on new collections deposited at the Universidade de São Paulo from three different horizons (I to III), previously studied by D.White (1908a) and probably associated with the Barro Branco and Bonito beds of Putzer (1952) 127 as seen in Table 1. In the same study, Rigby (1972a) also has detailed the phytofossil forms from another horizon which he considered older than the Bonito coal bed, on the Lauro Müller to Barro Branco road (0.5 to 1.0 miles) designated $\mathrm{BB}$ whose taphofloristic composition is also given in Table 1.

The Irapuá bed (the third coal bed from the base of the Siderópolis Member) consists of thin interbeds of coal and carbonaceous shale, reaching an overall average thickness of 


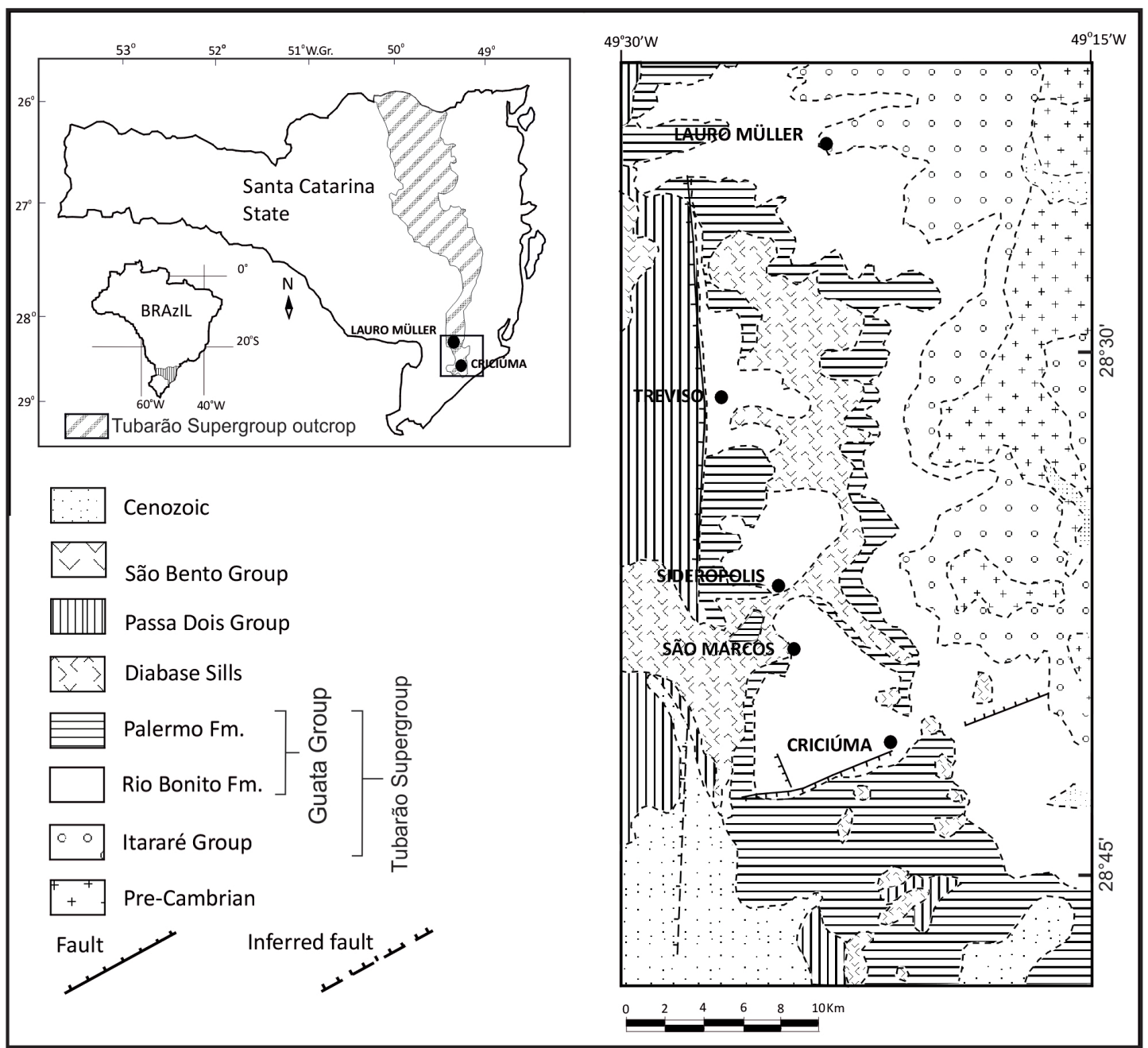

Figure 2. Map of the Santa Catarina coal region showing the geographic locations of the Siderópolis Member taphofloras in the State of Santa Catarina. Modified from Bernardes-de-Oliveira (1977).

2 to $3 \mathrm{~m}$ (see Figure 1) with lateral pinch outs over relatively short distances as seen in the outcrop at the Bainha locality (Iannuzzi, 2010). The beds containing plant fossils consist of clayey siltstone and fine to medium-grained sandstones that are interpreted as floodplain deposits formed primarily by deposition from suspension (over bank deposits) and secondarily by low-energy streams after flood events (Facies B and C of Iannuzzi, 2002). All these beds have been generated within a lagoon/barrier and/or fluvial system on a vast coastal plain (Putzer, 1952; Krebs, 2004).

Since the beginning of the second half of the twentieth century several authors have developed studies on plant fossiliferous levels in silty-clayey deposits associated with the Irapuá bed in Criciúma Municipality, State of Santa Catarina (Dolianiti, 1946, 1948, 1952, 1953a, 1953b, 1953c, 1954a, 1954b, 1956a, 1956b, 1971; Barbosa, 1958; Mussa, 1958; Millan, 1965, 1967a, 1967b, 1969a, 1969b, 1971; Yoshida, 1966, 1968; Rigby, 1969, 1972a, 1972b, 1972c; Bernardes-de-Oliveira, 1969, 1977, 1978, 1980a, 1980b, 1988; Rösler, 1973, 1975; Bernardes-de-Oliveira and Pontes, 1977; Bernardes-de-Oliveira and Carvalho, 1981; Bernardes-de-Oliveira and Yoshida, 1981).

Outcrops containing the Irapuá paleoflora are about $10 \mathrm{~m}$ thick, exposed along the south side of a small hill (Morro Cechinel) in the urban area of Criciúma and named as "Bainha", "Bairro 20" and "Hospital" and along the railway in the area of the coal loading station in the neighboring district of São Marcos, named as "São Marcos" (Bernardesde-Oliveira, 1977, 1980a). Plant fossils recovered from these outcrops represent a paleoflora informally called the Irapuá Bed flora (Bernardes-de-Oliveira, 1980a; Iannuzzi, 2010).

The Treviso bed was recognized by Putzer (1952) as the uppermost of the five layers of coal identified in Santa Catarina Coalfield (Figure 2). Read (1941) described a phytofossiliferous assemblage from Ferreira River margin outcrop (Treviso municipality) preserved in a silty-clayey 
Table 1. Siderópolis Member paleoflora in Lauro Muller, northern portion of the Santa Catarina Coalfield (after Rigby, 1972a).

\begin{tabular}{|c|c|c|}
\hline Bed & Horizon & Components \\
\hline \multirow[t]{3}{*}{$\begin{array}{c}\text { Barro Branco Coal } \\
\text { Bed }\end{array}$} & I or Joaquim Branco & $\begin{array}{l}\text { Lycopodiopsis sp. } \\
\text { Phyllotheca griesbachi Zeiller } \\
\text { Schizoneura gondwanensis Feistm. } \\
\text { Paracalamites australis Rigby } \\
\text { Sphenopteris lobifolia Morris } \\
\text { Gangamopteris obovata (Carr.) White } \\
\text { Glossopteris browniana Brongn. } \\
\text { G.communis Feistm. } \\
\text { G. occidentalis White } \\
\text { Vertebraria sp. } \\
\text { Arberia minasica (White) emend. Rigby } \\
\text { Derbyella aurita White } \\
\text { Noeggerathiopsis spathulata (Dana) Feistm. } \\
\text { Walikaliamillani Rigby } \\
\text { Gymnosperm branches } \\
\text { Samaropsis seixasi (White) Seward } \\
\text { S. moreirana (White) Dolianiti } \\
\text { S. mendesi Rigby } \\
\text { S. yoshidae Rigby } \\
\text { Cordaicarpus oliveiranus (White) Millan }\end{array}$ \\
\hline & II & $\begin{array}{l}\text { Lycophyte leaves } \\
\text { Paracalamites australis Rigby } \\
\text { Sphenopteris lobifolia Morris } \\
\text { Gangamopteris obovata (Carr.) White } \\
\text { Glossopteris ampla Dana } \\
\text { G. communis Feistm. } \\
\text { G. occidentalis White } \\
\text { Vertebraria sp. } \\
\text { Arberia minasica (White) emend. Rigby } \\
\text { Noeggerathiopsis spathulata (Dana) Feistm. } \\
\text { Cordaicarpus oliveiranus (White) Millan }\end{array}$ \\
\hline & III & $\begin{array}{l}\text { Gangamopteris obovata (Carr.) White } \\
\text { Glossopteris browniana Brongn. } \\
\text { Vertebraria sp. } \\
\text { Arberia minasica (White) emend. Rigby } \\
\text { Noeggerathiopsis spathulata (Dana) Feistm. } \\
\text { Samaropsis moreirana (White) Dolianiti } \\
\text { Cordaicarpus oliveiranus (White) Millan } \\
\end{array}$ \\
\hline $\begin{array}{c}\text { Older than BonitoCoal } \\
\text { Bed (?) }\end{array}$ & $\mathrm{BB}$ & $\begin{array}{l}\text { Lycopodiopsis sp. } \\
\text { Gangamopteris obovata (Carr.) White } \\
\text { Glossopteris browniana Brongn. } \\
\text { G.angustifolia Brongn. } \\
\text { G. communis Feistm. } \\
\text { Arberia minasica (White) emend. Rigby } \\
\text { Noeggerathiopsis spathulata (Dana) Feistm. } \\
\text { Samaropsis moreirana (White) Dolianiti } \\
\text { S. thomasi Schopf }\end{array}$ \\
\hline
\end{tabular}

level associated to the coal layer containing the following elements: Glossopteris cf. G. ampla Dana, G. indica Schimper, Lepidodendron pedroanum (Carruthers) Zeiller and Lepidostrobus sp., including this plant association in the Irapuá bed. Among the material collected later from the same outcrop, Lejal-Nicol and Bernardes-de-Oliveira (1979) identified a new lycophyte species, Cyclodendron brasiliensis. The richness in lycopsids and field observations lead to agree with Putzer's (1952) point of view and consider this plant horizon as belonging to Treviso bed.
These researches generated an extensive contribution to the knowledge of the floristic composition of the coal measures of Siderópolis Member, as detailed in Table 2-4.

\section{The most abundant paleofloristic components of the Siderópolis Member Paleoflora}

The glossopteridophytes, the most abundant elements in the Siderópolis Member Paleoflora, are represented by Glossopteris (Figures 4F and 5A-G), Gangamopteris (Figure 4A-E) (?) Rhabdotaenia (Figure 10A, B), Vertebraria and Ottokaria 


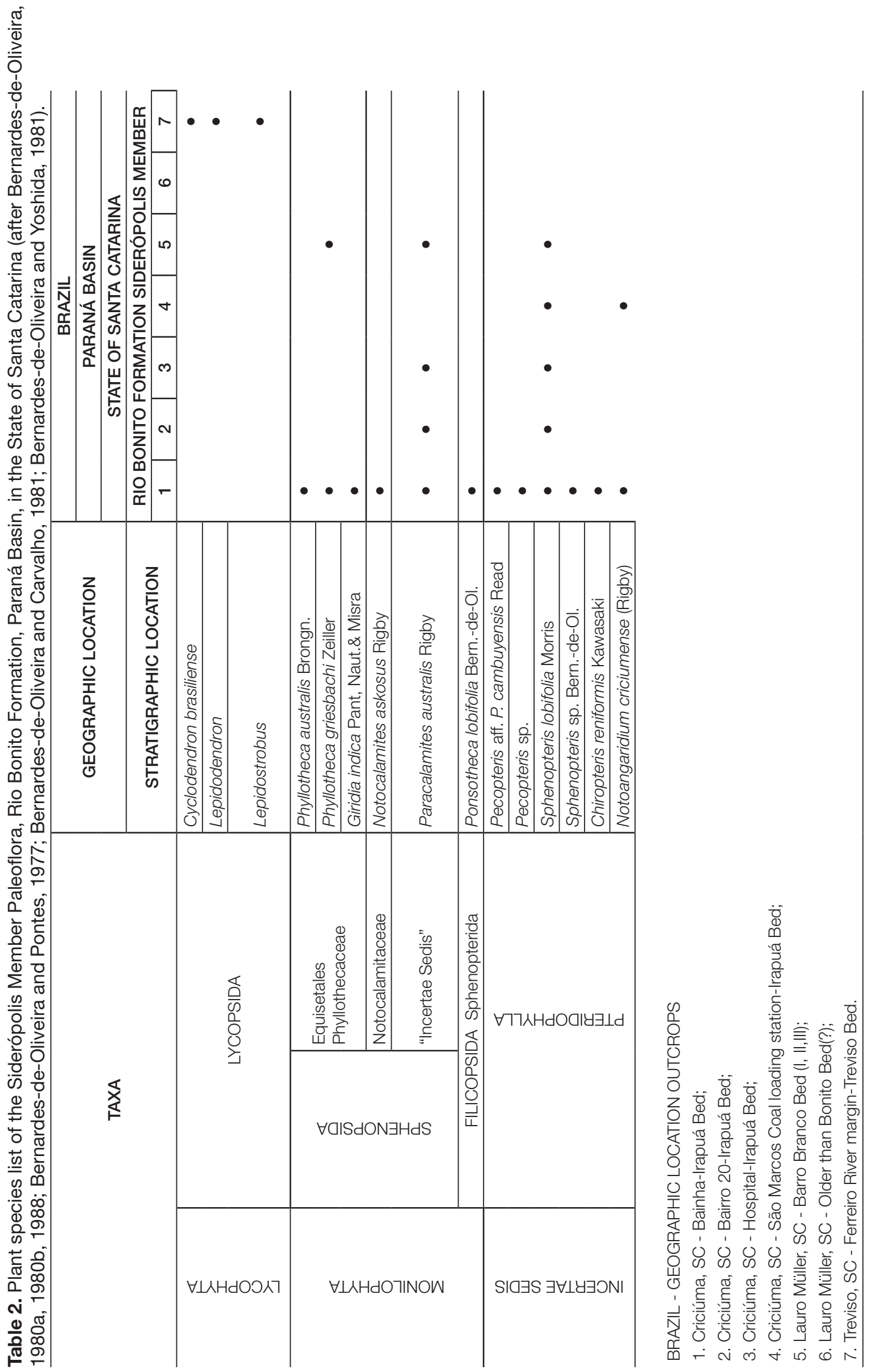




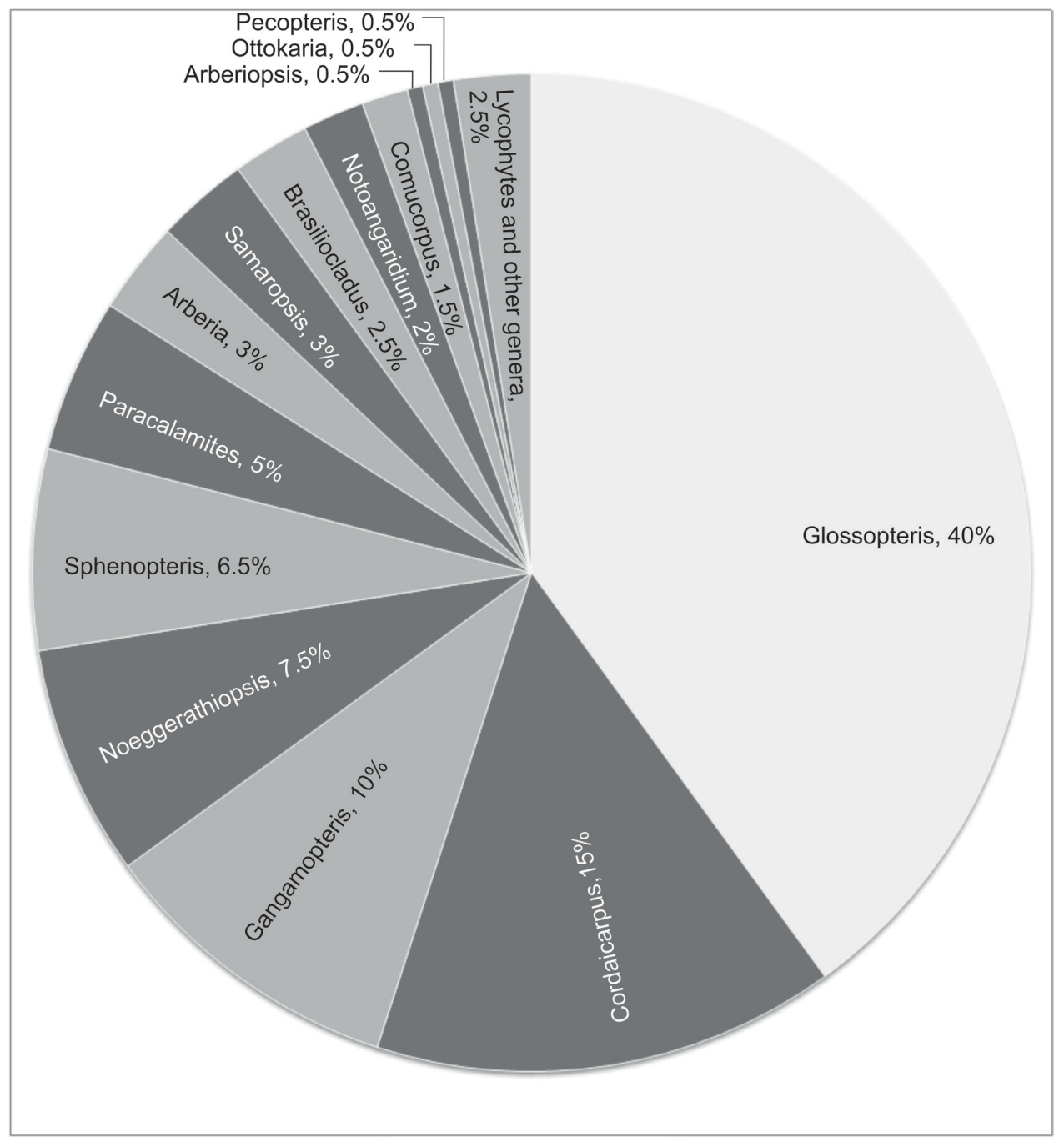

Figure 3. Quantitative representation of Siderópolis Member Paleoflora components. Modified from Bernardes-de-Oliveira, 1977.

(Figure 10G-J) genera and constitute more than $50 \%$ of the total plant association (Figure 3). The foliar genus Glossopteris, represented by eleven species, is dominant in the assemblage. The genus Gangamopteris is less abundant, constituting $10 \%$ of the total but yet diversified as represented by six species. The other glossopterid components account for less than $1 \%$ of the total.

Fertile fronds of filicophytes identified as Ponsotheca Bernardes-de-Oliveira (1980b) are rare (about $0.1 \%$ of the total composition), but sterile fronds (pteridophylles) which could correspond to filicophytes or pteridospermophytes like Sphenopteris, Pecopteris and Notoangaridium, constitute $9 \%$ of the total floristic composition (Figures $6 \mathrm{~A}-\mathrm{C}$ and $7 \mathrm{E}$ ).

The cordaitophytes, represented by the genus Noeggerathiopsis, constitute $7.5 \%$ of the total association thus corresponding to the third group in abundance (Figure 8A-C).

The sphenophytes constitute about $5.5 \%$ of the paleoflora and are commonly represented by Paracalamites (5\%), while other vegetative forms (Phyllotheca) and reproductive structures (Notocalamites) are rare (Figure 9A-G).

Delicate sterile shoots of coniferophytes such as Brasiliocladus Bernardes-de-Oliveira and Yoshida (1981) and few specimens of Buriadia associated to Cornucarpus seeds constitute about $4 \%$ of the paleoflora (Figure 7A-G).

Fructifications like Arberia and Arberiopsis Bernardes-deOliveira (1978) are here considered in the pteridospermophytes, corresponding to $3.5 \%$ of the total paleoflora (Figure 10C-F). The dispersed seeds of the genera Cordaicarpus (Figure 8D-F) and Samaropsis (Figure 8G-J) tentatively included in this plant group constitute $15 \%$ and $3 \%$ of the total plant association respectively.

The lycophytes are absent in most outcrops of the Siderópolis Member paleoflora but show an almost exclusive assemblage in the Ferreira River outcrop in Treviso Municipality (Figure 11A-C). 


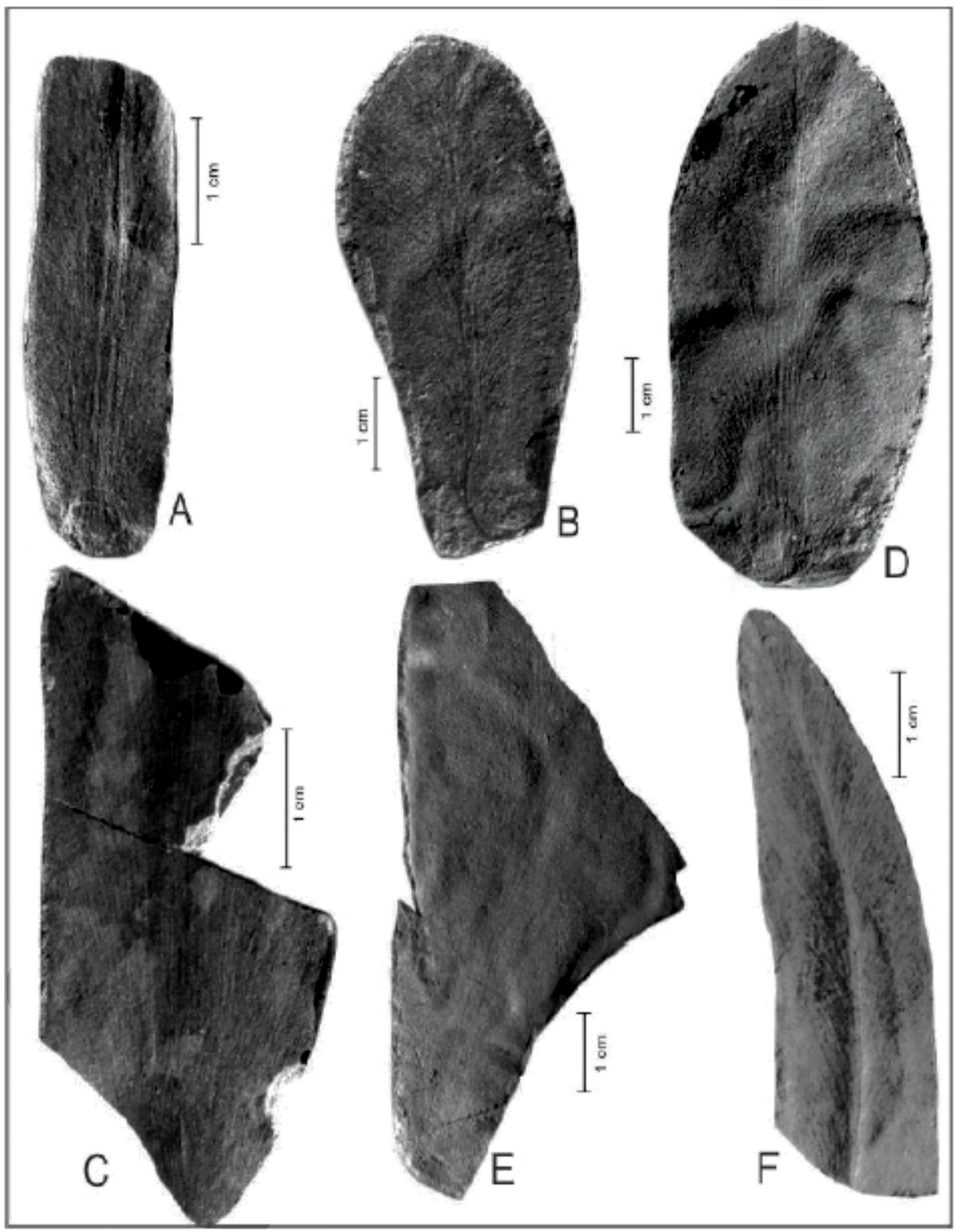

Figure 4. A-F. Irapuá coal seam, Municipality of Criciúma, SC: (A) Gangamopteris sp., GP/3T-175 from São Marcos; (B) Gangamopteris intermedia, GP/3T-221 from Bainha; (C) Gangamopteris cf. G. buriadica, GP/3T-215 from Bainha; (D) Gangamopteris mosesii, GP/3T-218 from Bainha; (E) Gangamopteris obovata, GP/3T-211 from Bainha; (F) Glossopteris angustifolia, GP/3T-178 from São Marcos. 
Table 3. Plant species list of the Siderópolis Member Paleoflora, Rio Bonito Formation, Paraná Basin, in the State of Santa Catarina. (For legend see Table 2).

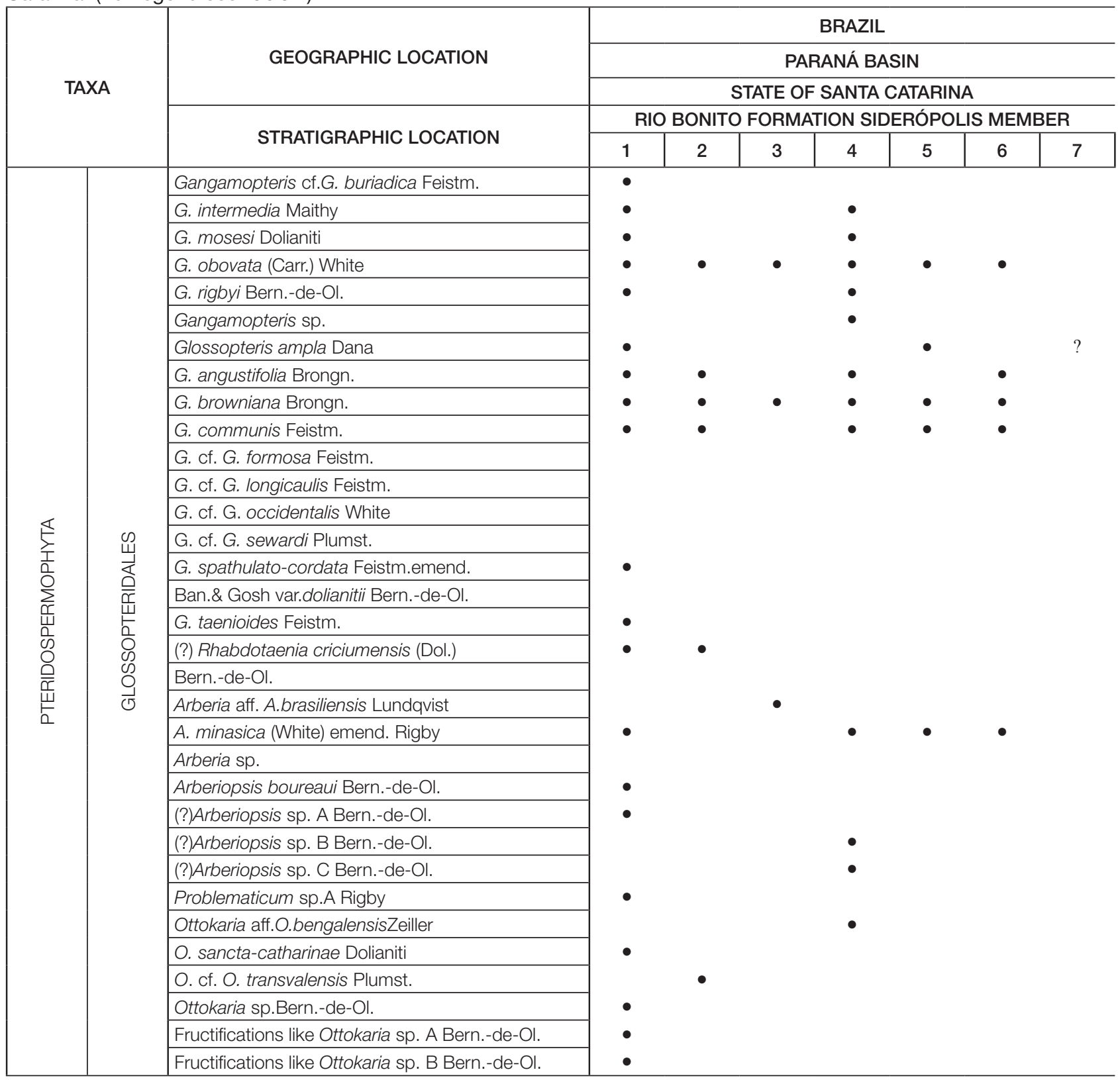

\section{Some paleoenvironmental aspects of the Siderópolis Member Paleoflora}

Considering that taphofloras are almost always formed by autochthonous and allochthonous material and that the vegetation registered by several taphofloras has undergone distinct selection process due to transport from different sources to distinct depositional areas, it is possible to propose distribution models for the species. Thus, the phytofossil assemblages show their paleoecology as much as biostratinomy.

Botrychiopsis, Phyllotheca and Lycophyte association is related with meso-hydrophilic environments, whilst ferns and glossopterids with mesophilic environment. Low diversity of the specimens is considered as a result of inherent abiotic stress areas of flooding at high latitudes that are stable for a long period of time (Guerra-Sommer, 1989).

Although the paleoflora of Siderópolis involves several taphofloras from larger or smaller distances between them, it is possible to infer ecological features present in these phytofossil records.

1) The taphofloras of the Bairro 20 and Hospital outcrops (Criciúma, SC) - rich in seeds and some stems, could be related to deposits more distal in aqueous body of the 


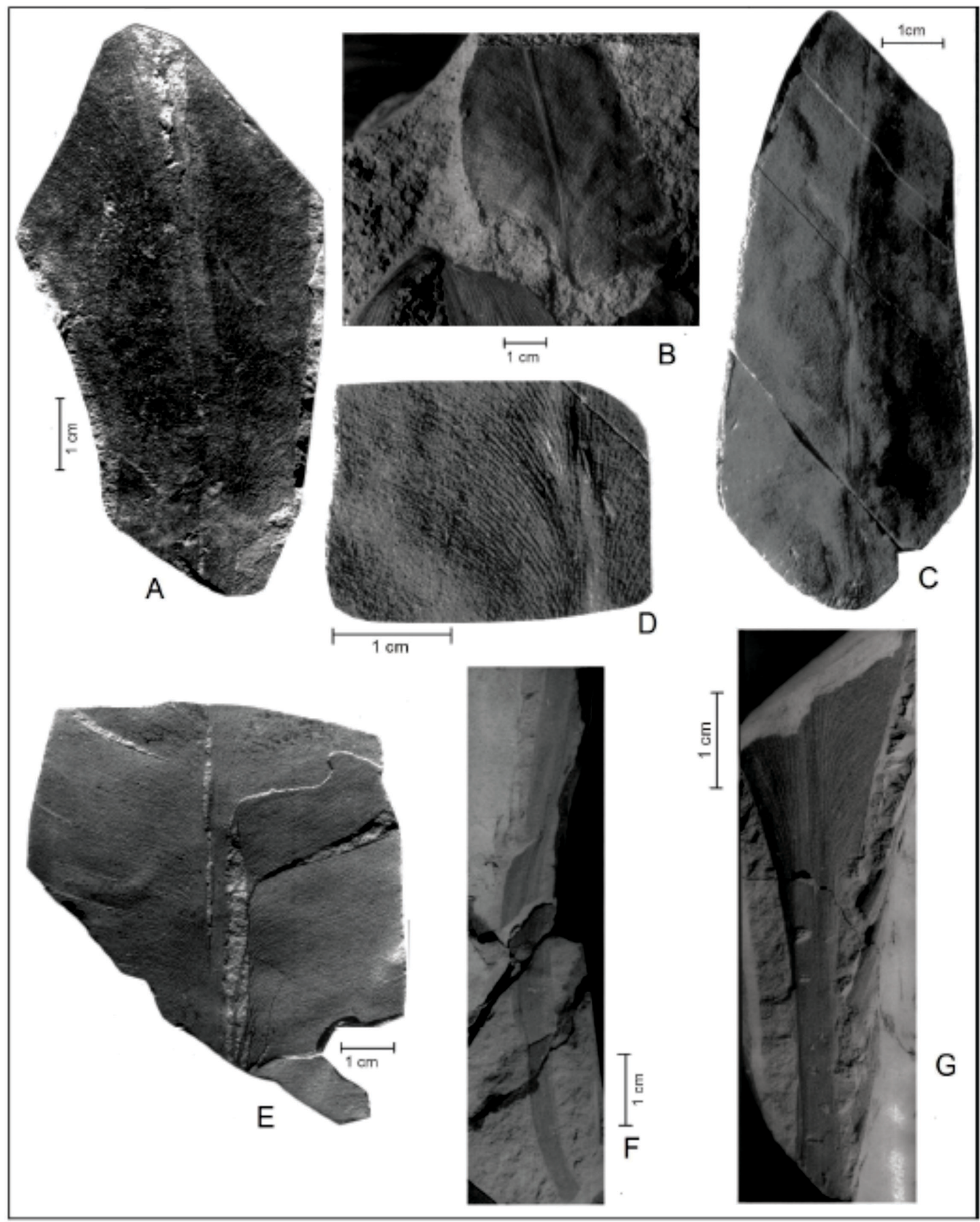

Figure 5. A-G. (A, C, D, E, F, and G from Irapuá coal seam, Criciúma, SC); (B from Barro Branco coal seam, Lauro Müller, SC). (A) Glossopteris browniana, Bairro 20, GP/3T-188; (B) G. communis, Barro Branco, GP/3T; (C) G. communis, Bainha, GP/3T-193; (D) G. communis detail of GP/3T-193; (E) G. cf. G. occidentalis, Bainha, GP/3T-227; (F) G. taenioides, Bainha, GP/3T-203; (G) G. cf. G. longicaulis, São Marcos, GP/3T-180. 


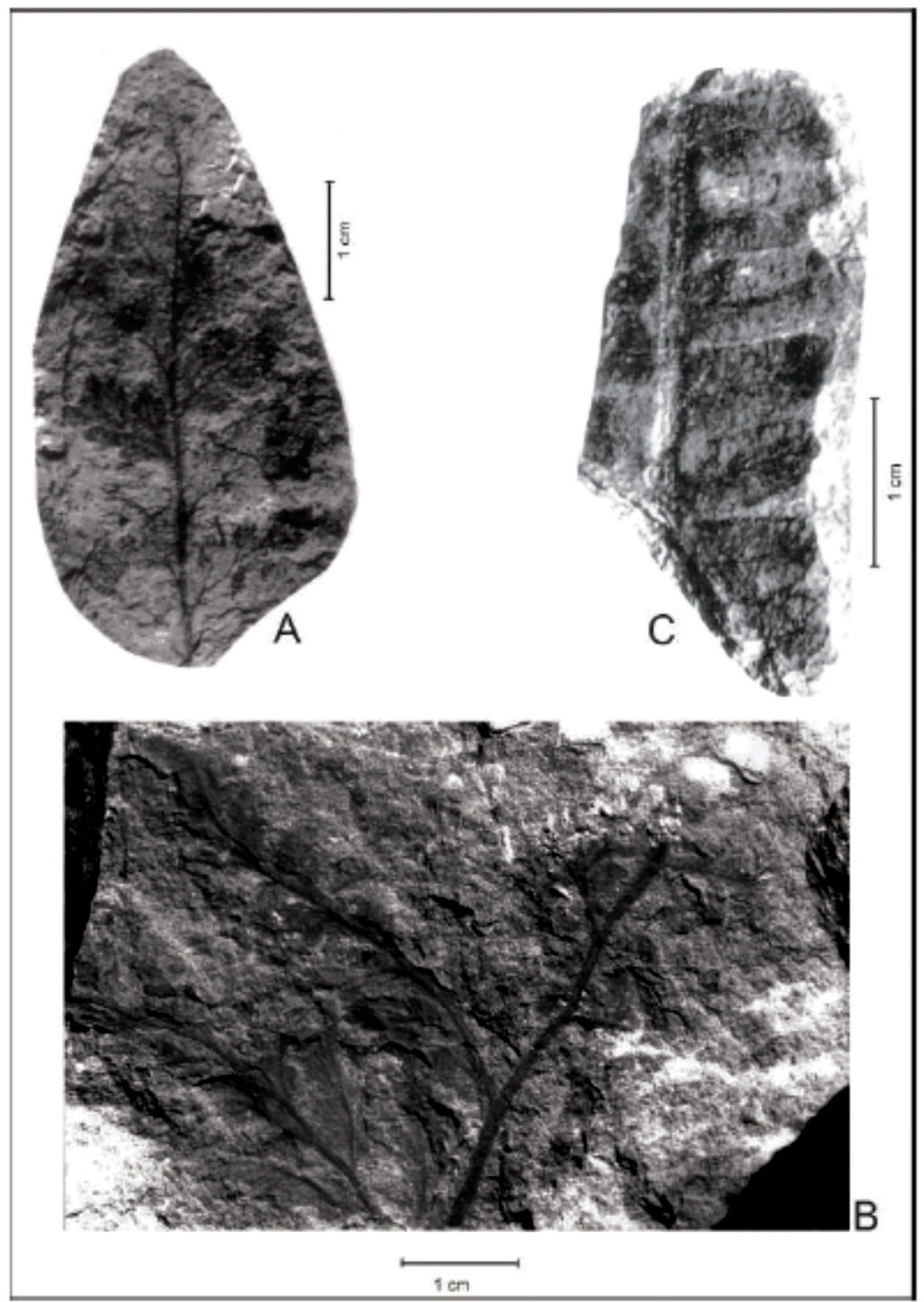

Figure 6. A-C. Irapuá coal seam, Criciúma, Municipality, SC. (A) Sphenopteris lobifolia GP/3T-144; (B) Ponsotheca lobifolia DNPM-1176 both from Bainha; (C) Pecopteris sp. from São Marcos, GP/3T-149.

sedimentation. Bainha and São Marcos outcrops (also in Criciúma, SC), richer in leaf, leafy branches and forms of fruiting bodies, could be related to proximal environments within a deltaic system. The Treviso taphoflora may have been deposited in a more brackish transitional environmentrepresenting a marshy plant community, formed by endemic elements such as Brasilodendron pedroanum, Cyclodendron brasiliense and rare allochthonous glossopterids.

2) Bainha and São Marcos outcrops represent deltaic deposits which would be deposited near flood plain community elements since they are rich in sphenophytes and mesophilic elements such as glossopterid leaves and fructifications, very rare forms of lycophytes (possibly from brackish waters of mangrove type) and rare coniferous remains (related to distant highland forms).
3) The dominance of a lycophyte assemblage, almost pure and mutually exclusive in the Treviso bed in relation to the other plant groups, as seen in Lejal-Nicol and Bernardes-de-Oliveira (1979), may be related to some typical conditions evident in brackish (i.e. tidal flats), distal deltaic or mangrove paleoenvironments.

\section{Correlation of Siderópolis Member Paleoflora with other Permian Southern Brazil paleofloras}

The typical postglacial Glossopteris paleoflora of the Siderópolis Member of Santa Catarina State differs from the pre glossopterid interglacial taphofloras of the lower and middle stages of Itararé Group registered in different sites of the State of São Paulo namely, Bandeirantes Highway 96 km, 


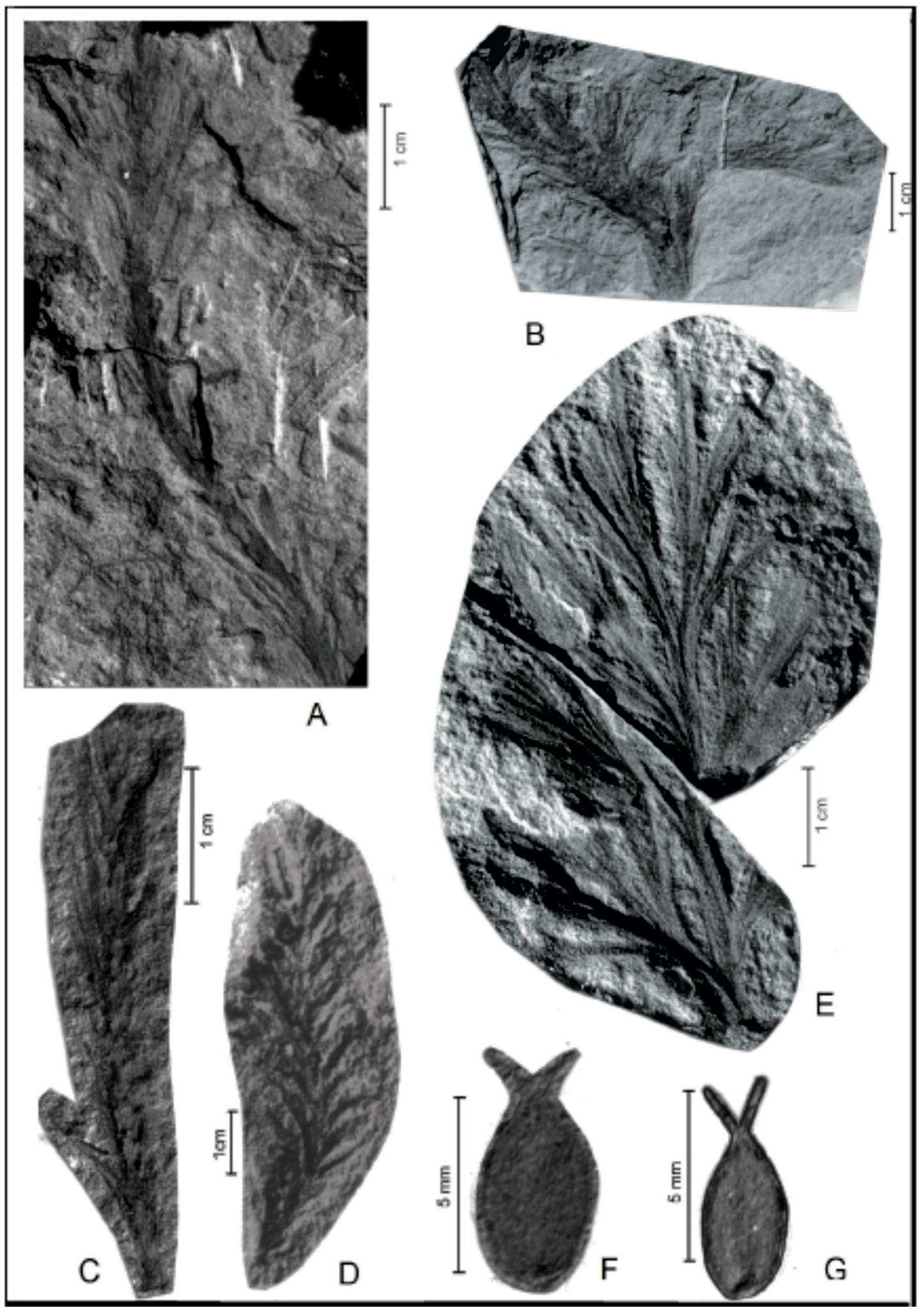

Figure 7. A-G. Irapuá coal seam, Criciúma, SC. (A, B, C) Brasiliocladus acicularis from Bainha, (A) DGP-7/1051, (B) GP/3T-250, (C) GP/3T-265; (D) Buriadia mendesi from Bainha, DGP-7/1057 (Holotype); (E) Notoangaridium criciumensis from São Marcos, GP/3T-166; (F, G) Cornucarpus furcatus, (F) From São Marcos, GP/3T-169, (G) From Bainha, GP/3T-171. 
Itapeva, Monte Mor, and Salto de Itu by the absence of glossopterids in these late Pennsylvanian associations. It is also distinguished from the glossopterid interglacial Asselian taphoflora of Cerquilho (SP), included in the uppermost part of the Itarare Group, by the absence of the genus Glossopteris in that taphoflora (Bernardes-de-Oliveira et al., 2005).

Taphofloras from the immediate postglacial interval of São João do Triunfo and Figueira (State of Paraná, Triunfo
Member, basal portion of the Rio Bonito Formation) evidenced a composition characterized by a less diverse flora with predominance of the genus Gangamopteris over Glossopteris (Rösler, 1972, 1979; Ricardi-Branco, 1998; Ricardi-Branco and Rösler, 2004) different from the Siderópolis Member paleoflora, where the genus Glossopteris is dominant in a proportion of 4:1 over Gangamopteris and shows a higher diversity.

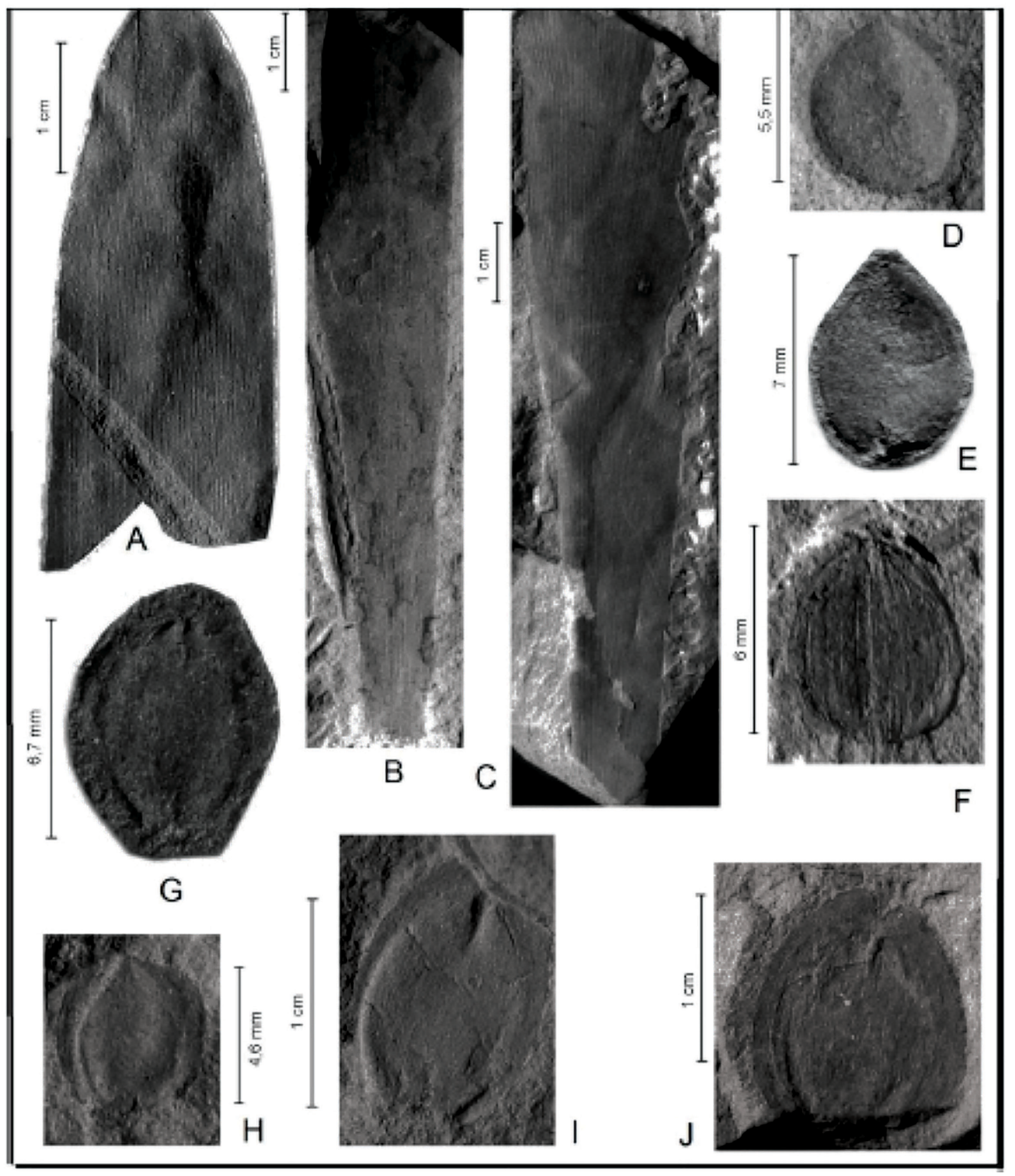

Figures 8. A-J. Irapuá coal seam, Criciúma, SC. (A, B, C) Noeggerathiopsis hislopi (A) GP/3T-255, (B) GP/3T-259 both from Bainha, (C) GP/3T-260 from São Marcos; (D) Cordaicarpus irapuensis, GP/3T-168 (Holotype) from Hospital; (E) Cordaicarpus rocha-camposi GP/3T-162 from Bainha; (F) Cordaicarpus zeilleri, GP/3T-160 from Bainha; (G, H) Samaropsis millaniana: (G) GP/3T-155 (Holotype), (H) GP/3T-170 both from Bainha; (I, J) Samaropsis sancti-marci, (I) GP/3T-186, (J) GP/3T-200 both from São Marcos. 
In the State of Rio Grande do Sul, at the Morro do Papaléo Mine section in the Municipality of Mariana Pimentel two depositional sequences have been recognized, the lower one is assigned to a lagoonal / lacustrine facies of the final deposits of the Itararé Group and the upper one to deposits of a fluvial facies of the Rio Bonito Formation (Guatá Group) (Iannuzzi et al.,
2007). The floral assemblages from the Morro do Papaléo Mine occur within distinct stratigraphic levels of both facies. The studies of Corrêa da Silva and Arrondo (1977), Corrêa da Silva (1978), Burjack et al. (1982) and Cazzulo-Klepzig and Guerra-Sommer (1983) are restricted to the floral record found in the lowermost section corresponding to the Itararé Group.

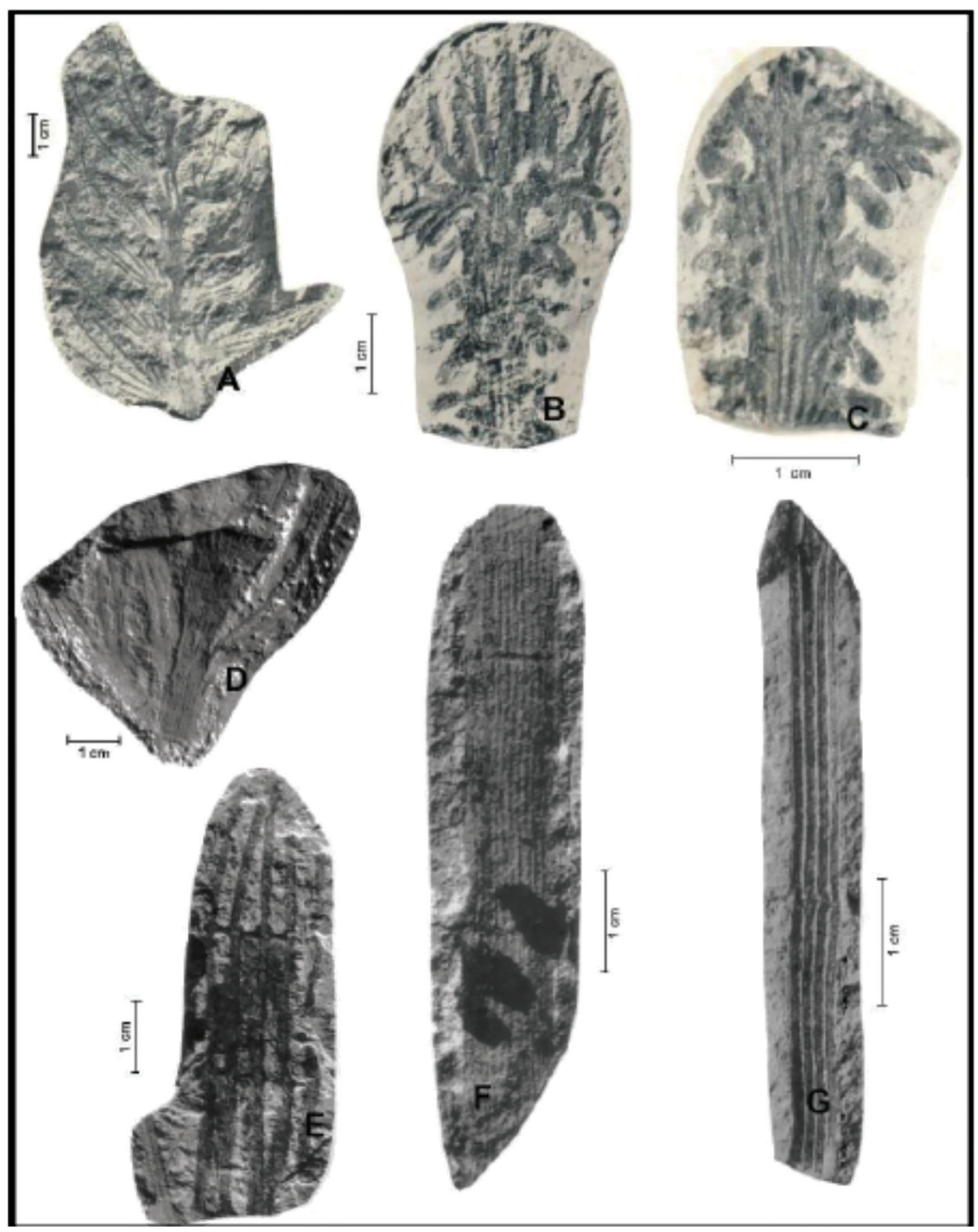

Figure 9. A-G. (A) Joaquim Branco coal seam, Lauro Müller Municipality, SC; (B-G) Irapuá coal seam, Criciúma Municipality, SC. (A) Phyllotheca griesbachi, Joaquim Branco coal seam, DGP7/1161; (B, C) Notocalamites askosus from Bainha, DGP7/1054; (D) Phyllotheca australis from Bainha, GP/3T-139; (E, F, G) Paracalamites australis from Bainha, (E) GP/3T-142, (F) GP/3T-140, (G) GP/3T-141. 


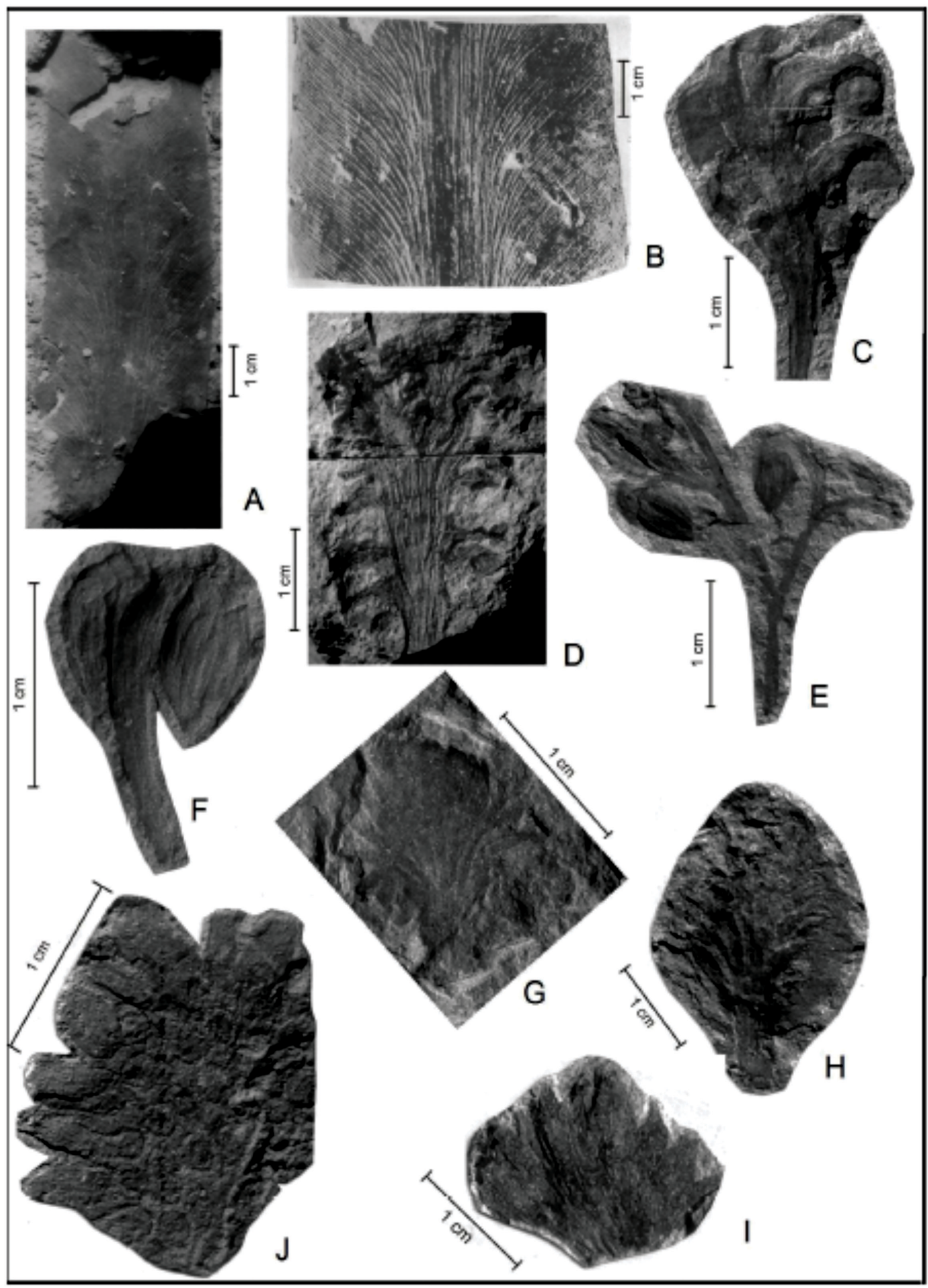

Figure 10. (A, J). Irapuá coal seam, Criciúma, SC. (A, B) ?Rhabdotaenia criciumensis from Bairro 20, (A) GP/3T- 209, (B) GP/3T-208; (C, D) Arberia minasica from Bainha, (C) GP/3T-235, (D) GP/3T-244; (E) Arberiopsis boureaui, GP/3T-238 (Holotype) from Bainha; (F) Arberiopsis sp.B., GP/3T-239 from São Marcos; (G) Ottokaria aff. O. bengalensis, GP/3T-192 from São Marcos; (H) Ottokaria sp., GP/3T-233 from Bainha; (I) Ottokaria cf. O. transvalensis, GP/3T-245 from Bairro 20; (J) Ottokaria sanctae-catharinae, GP/3T-232 from Bainha. 


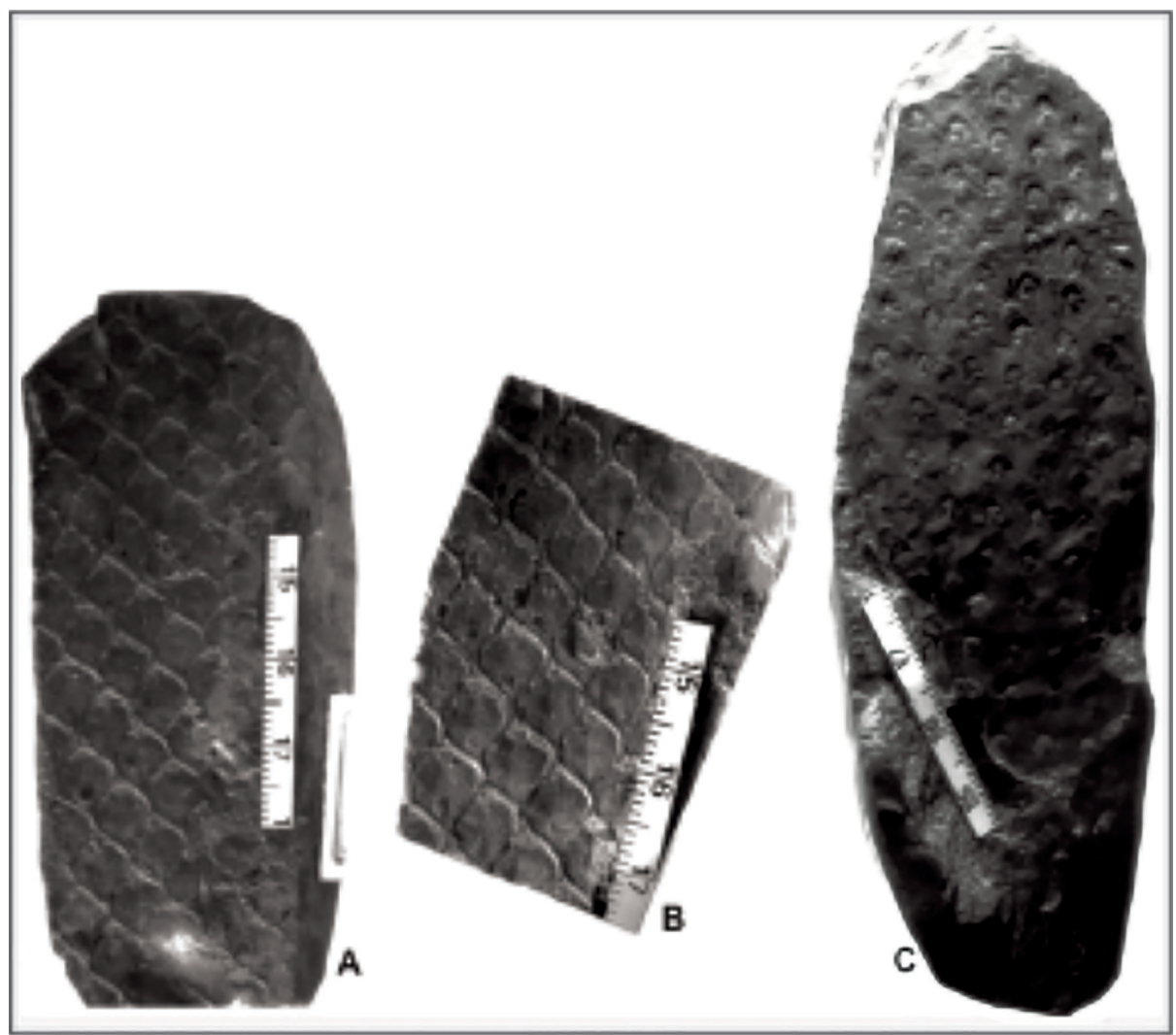

Figure 11. (A-C) Cyclodendron brasiliensis, (A,B)-TR-49, (C)- TR-47 all from Treviso,SC, Ferreira River.

These assemblages bear few species of the genus Glossopteris indicating probably a younger floristic level than Cerquilho, in the State of São Paulo, and may be contemporaneous to the Triunfo Member in the State of Paraná.

The upper sequence of the Morro do Papaléo section related to the coal measures of the Rio Bonito Formation contains two phytofossiliferous beds, N7 and N8 as described by Iannuzzi et al. (2003a, 2003b, 2009). The plant-bearing beds of the uppermost section of the Morro do Papaléo were described as two fossiliferous beds containing records of Gangamopteris (G.obovata var. major), Glossopteris (G.indica, G. communis, G. occidentalis), ginkgoalean (Ginkgophytopsis sp.), cordaitalean leaves (Cordaites hislopi = Noeggerathiopsis hislopi), as well as ferns (Asterotheca sp., Pecopteris spp.), abundant lycopsid stems of Brasilodendron pedroanum, Cordaicarpus and Samaropsis-type seeds (Vieira and Iannuzzi, 2000; Iannuzzi et al. (2003a, 2003b). The floristic association was included in the base of the Siderópolis Member by Iannuzzi (2010).

Undoubtedly, these floras have close similarities with the Siderópolis Member paleoflora but they show minor diversification than the latter in relation to the sphenophytes, the glossopterid leaves and fructification species, the seeds of Cordaicarpus spp and Samaropsis spp. Nevertheless, the absence of Asterotheca and Ginkgophytopsis in Siderópolis
Member can represent stratigraphic or paleoecological/ paleoclimatic factor.

The Quitéria flora was first reported by Piccoli et al. (1991) from the Municipality of Encruzilhada do Sul, around $100 \mathrm{~km}$ southwest of Porto Alegre city. The outcrop corresponds to the uppermost strata of Rio Bonito Formation in the State of Rio Grande do Sul. This outcrop was divided into two distinct sedimentary units (Piccoli et al., 1991; Jasper et al., 2006) with two phytofossiliferous levels. The lower level of fossil plants from a dark gray massive mudstones that underlie a succession of thin coal seams, according to Piccoli et al. (1991) and Guerra-Sommer et al. (1995), Boardman and Iannuzzi (2010) and Boardman et al. (2012), is predominantly composed of articulated stems (Paracalamites sp.) and Phyllothecalike leaf branches. Although less abundant, the glossopterid leaves (Glossopteris communis) and pteridophylla fronds (Rhodeopteridium sp.) still occur and with less common fertile structures (Arberia minasica; Gondwanostachys australis = Giridia quiteriensis) and seeds (Cordaicarpus sp.).

The upper level of phytofossils contain abundant stumps and stems of arborescent lycophytes in situ (Brasilodendron pedroanum), remains of pteridophylla fronds (Botrychiopsis valida, B. plantiana and Rhodeopteridium sp.), fertile and sterile leafy shoots of conifers (Coricladus quiteriensis), rare leafy branches of lycopodiales (Lycopodites riograndensis), 
Table 4. Plant species list of the Siderópolis Member Paleoflora, Rio Bonito Formation, Paraná Basin, in the State of Santa Catarina. (For legend see Table 2).

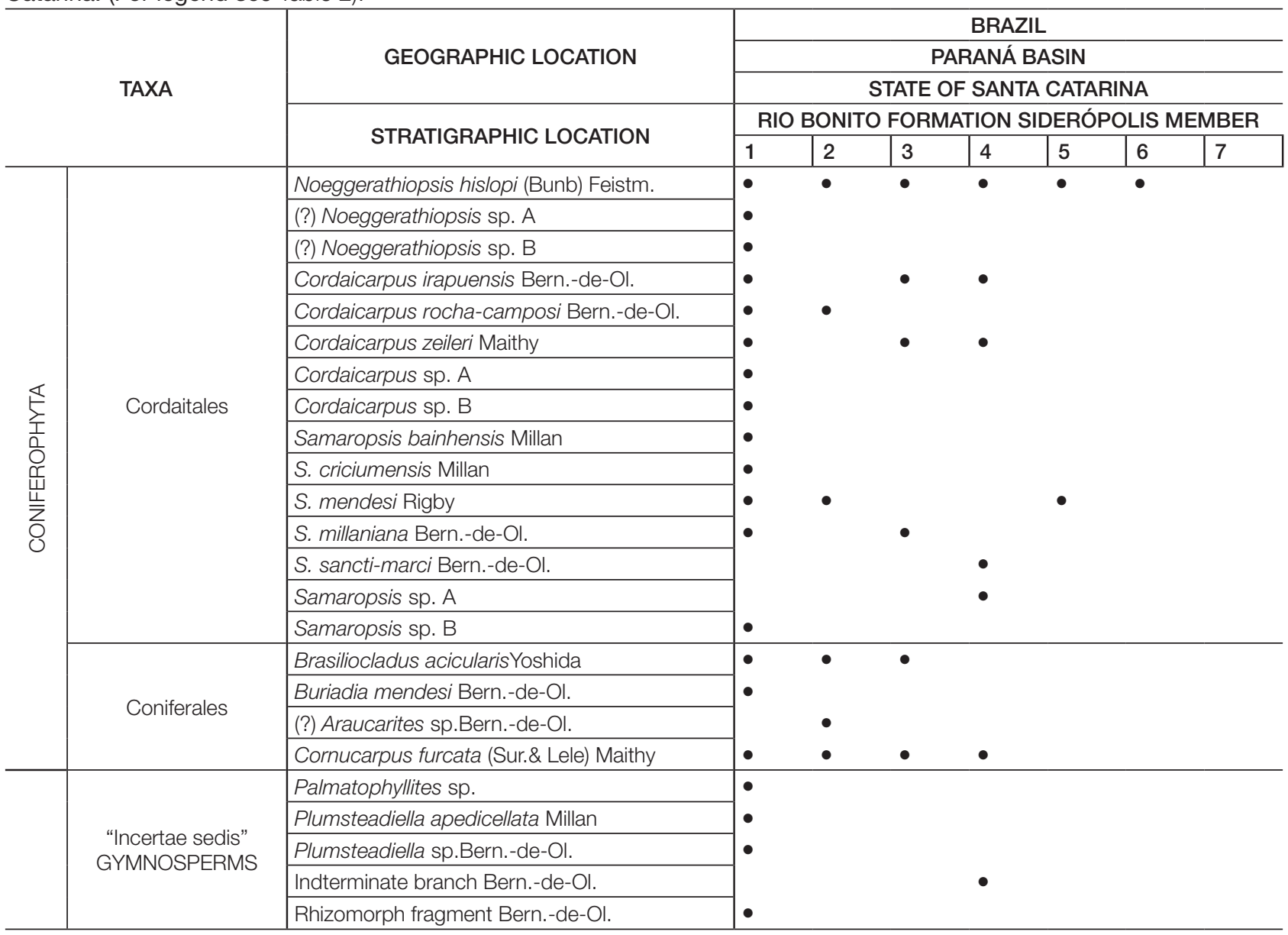

and glossopterid leaves (Glossopteris browniana and Gangamopteris buriadica) (Jasper et al., 2005; Jasper et al., 2006; Boardman et al., 2006; Guerra- Sommer et al., 2008; Tybusch and Iannuzzi, 2008; Iannuzzi and Boardman, 2008; Iannuzzi, 2010; Boardman et al., 2012).

Iannuzzi (2010) placed the Quitéria floras in a stratigraphical interval at the transition from the Paraguaçu to Siderópolis members of the State of Santa Catarina, assigning an approximate age of 288-285 Ma (Artinskian, according Cohn et al., 2013, updated).

These Quitéria taphofloras show many forms in common with the paleoflora of the Siderópolis Member, however, are different due to the minor diversity of Glossopteris and Gangamopteris species, the presence and diversification of the Botrychiopsis (B. plantiana, B. valida) and the presence of Asterotheca-type fronds and of fertile and sterile leafy shoots of conifer Coricladus., all three genera absent in Siderópolis paleoflora.

Nevertheless, the absence of these genera in Siderópolis Member paleoflora could be due to stratigraphic or paleoecological/paleoclimatic factor.

\section{FINAL REMARKS}

The Siderópolis Member Paleoflora is dominated by glossopterid leaves, with the genus Glossopteris predominant over Gangamopteris, followed by cordaitalean leaves (Noeggerathiopsis) and seeds (Cordaicarpus, Samaropsis, Cornucarpus), fronds are common (Sphenopteris, Pecopteris and Notoangaridium) while reproductive structures of glossopterids or other groups (Arberia, Arberiopsis, Ottokaria, Plumsteadiella) and conifer leaf shoots (Brasiliocladus, Buriadia) are rare. Concerning to other early Permian floras throughout Paraná Basin, the Siderópolis Paleoflora distinguishes itself by the highest diversity of forms and the presence of several exclusive taxa in both levels, specific (Buriadia mendesi, Cordaicarpus rocha-camposi, C. irapuenses, Gangamopteris rigbyi, Glossopteris spathulato-cordata var. dolianitii, Samaropsis bainhensis, S. criciumensis, S. millaniana, S. mendesi) and generic (Arberiopsis, Brasiliocladus, Notoangaridium, Notocalamites, Ponsotheca, Cyclodendron). 
The only comparable paleofloras were registered in two outcrops namely, Morro do Papaléo (upper section) and Quitéria, of Rio Bonito Formation from the State of Rio Grande do Sul. However, these floras are quite less diversified and do not show several typical taxa of the Siderópolis paleoflora, while other elements are restricted to them (e.g. Ginkgophytopsis sp., Rhodeopteridium sp., Kawizophyllum sp., Botrychiopsis spp., Coricladus quiteriensis, Lycopodites riograndensis, Giridia quiteriensis). These differences can be explained by the distinct stratigraphic position, the Siderópolis paleoflora being apparently situated above in relation to the southern paleofloras (Iannuzzi, 2010). However, paleoecological/paleoclimatic factors should not be ruled out in order to justify this dissemblance.

\section{ACKNOWLEDGEMENTS}

This work is a contribution to the Project of International Scientific Collaboration between Brazil and India "Palaeobotanical Studies in Brazilian and Indian Sedimentary Basins with special reference to the marine dinoflagellate cysts, Gondwana Flora and their applications" sponsored by Brazil-CNPq 490829/2007-4 and India-DST RPO 24/2007. The authors thank the CNPq, Brazil and the DST, India for providing the financial support to carry out the study. Some authors are participants of the Fellowship Program in Research Productivity of CNPq (\# PQ 304978/ 2013-2 MECBO; PQ 306609/2012-6 - MJG; PQ 309211/2013-1 - RI; PQ301585/2012-1 - MGS; PQ 301585/2012-1 - AJ). MJG is grateful to PNPD-CAPES Post Doctoral Scholarship. The author PSK is thankful to the CNPq for the BJT Scholarship, No. 300578/2015-6 of the Science without Frontiers Program and to the Birbal Sahni Institute of Palaeosciences for the permission to come to Brazil. The author MS is thankful to the CNPq for the PDJ Scholarship, No. 150574/2015-0.

\section{REFERENCES}

Barbosa, O. (1958). On the age of the Lower Gondwana floras in Brazil and abroad. Congreso Geológico Internacional. XX Sesión, Comisión de Gondwana, 205-236. Ciudad de México.

Bernardes-de-Oliveira, M. E. C. (1969). Flora da Formação Rio Bonito: Glossopteris, Noeggerathiopsis, Sphenopteris, Gangamopteris e Rhabdotaenia, na subida do Bainha, Criciúma, Santa Catarina. Dissertação (Mestrado). São Paulo: Faculdade de Filosofia, Ciências e Letras - USP.

Bernardes-de-Oliveira, M. E. C. (1977). Tafoflora Eogondvânica da camada Irapuá, Formação Rio Bonito (Grupo Tubarão), $S C$. Tese (Doutorado). São Paulo: Instituto de Geociências - USP.
Bernardes-de-Oliveira, M. E. C. (1978). Frutificações de pteridospermófitas eogondvânicas da Camada Irapuá, Formação Rio Bonito, nos arredores de Criciúma, SC. XXX Congresso Brasileiro de Geologia, v. 2, 986-1001. Recife: SBG.

Bernardes-de-Oliveira, M. E. C. (1980a). Tafoflora eogondvânica da Formação Rio Bonito (Camada Irapuá), Bacia do Paraná, Brasil. II Congreso Argentino de Paleontología y Bioestratigrafia / I Congreso Latinoamericano de Paleontología, v. 6, 69-88. Buenos Aires: APA.

Bernardes-de-Oliveira, M. E. C. (1980b). Nouveau genre néomarioptériden fertile de la Flora à Glossopteris du Bassin de Paraná, au Brésil. Boletim IG-USP, 11, 113-119.

Bernardes-de-Oliveira, M. E. C. (1988). Equisetales eogondvânicas da Tafoflora Irapuá, Formação Rio Bonito (Permiano Inferior). Anais da Academia Brasileira de Ciencias, 60, 45-60.

Bernardes-de-Oliveira, M. E. C., Carvalho, R. G. (1981). Frutificações femininas de Glossopteridófitas da Formação Rio Bonito, Grupo Tubarão, Estado de Santa Catarina, Brasil. II Congresso Latinoamericano de Paleontologia, v. 1, 181-199. Porto Alegre: UFRGS.

Bernardes-de-Oliveira, M. E. C., Pontes, C. E. S. (1977). Algumas observações sobre cordaitófitas da Formação Rio Bonito, Grupo Tubarão, Bacia do Paraná, Brasil. I Congreso Geológico Chileno, v. 3, L21-L81. Santiago.

Bernardes-de-Oliveira, M. E. C., Rohn, R., Ricardi-Branco, F., Zampirolli, A. P., Mune, S. E., Amaral, P. G. C., Longhim, M. E., Castro-Fernandes, M. C., Lages, L. (2005). Late Carboniferous to Early Permian glacial related paleofloras from northeastern Paraná Basin, Brazil. 12 Gondwana, 69. Mendoza: AGA.

Bernardes-de-Oliveira, M. E. C., Yoshida, R. (1981). Coniferófitas da Tafoflora Irapuá, Formação Rio Bonito, Grupo Tubarão, em Santa Catarina. Boletín Asociación Latinoamericana de Paleobotánicos y Palinólogos, 8, 39-55.

Boardman, D. R., Iannuzzi, R. (2010). Presence of the genus Giridia in the Paraná Basin (Lower Permian, Rio Bonito Formation). Revista Brasileira de Paleontologia, 13, 5-12.

Boardman, D. R., Souza, P. A., Iannuzzi, R., Mori, A. L. O. (2012). Paleobotany and palynology of the Rio Bonito Formation (Lower Permian, Paraná Basin, Brazil) at the Quitéria Outcrop. Ameghiniana, 49, 451-472.

Boardman, D. R., Tybusch, G. P., Iannuzzi, R., Dutra, T. L., Lima, L. (2006). Presença de Glossopteris browniana Brongniart em níveis do topo do afloramento Quitéria (Formação Rio Bonito), Rio Grande do Sul, Brasil (Permiano Inferior). Gaea, 2(1), 9-17.

Bortoluzzi, C. A., Piccoli, A. E. M., Bossi, G. E., GuerraSommer, M., Marques-Toigo, M., Pons, M. E. H., Wolf, 
M., Silva, Z. C. C. (1978). Pesquisa geológica na Bacia Carbonífera de Santa Catarina. Pesquisas, 11, 33-192.

Burjack, M. I. A., Cazzulo-Klepzig, M., Dias-Fabrício, M. A., Guerra-Sommer, M., Marques-Toigo, M., Paim, P. S., Lavina, E. L. (1982). Perfil paleoecológico do afloramento Morro do Papaléo, Permiano Inferior da bacia do Paraná, Rio Grande do Sul, Brasil. 32 Congresso Brasileiro de Geologia. v. 4, 1260-1270. Salvador: SBG.

Cazzulo-Klepzig, M., Guerra Sommer, M. (1983). Relationship between the taphoflora of the Itararé Group, Paraná Basin, South Brazil and the Permocarboniferous boundary. $X$ Congreso Internacional Estratigrafia y Geologia del Carbonifero, 395-407. Madrid.

Cazzulo-Klepzig, M., Guerra-Sommer, M., Menegat, R., Simas, M. W., Mendonça Filho, J. G. (2007). Peat-forming environment of Permian coal seams from the Faxinal coalfield (Paraná Basin) in Southern Brazil, based on palynology and palaeobotany. Revista Brasileira de Paleontologia, 10(2), 117-127.

Cazzulo-Klepzig, M., Menegat, R., Guerra-Sommer, M. (2005). Palynology and paleobotany in the reconstruction of landscape units from the Candiota Coalfield, Permian of Paraná Basin, Brazil. Revista Brasileira de Paleontologia, 8, 83-98.

Cohen, K. M., Finney, S. C., Gibbard, P. L., Fan, J. X. (2013). The ICS International 525 Chronostratigraphic Chart. Episodes, 36, 199-204.

Corrêa da Silva, Z. C. (1978). Observações sobre o Grupo Tubarão no Rio Grande do Sul com especial destaque à estratigrafia da Formação Itararé. Pesquisas, 9, 9-62.

Corrêa da Silva, Z. C., Arrondo, O. G. (1977). Tafoflora Permiana de Mariana Pimentel, Município de Guaíba, Rio Grande do Sul, Brasil. Pesquisas, 7, 27-44.

Dolianiti, E. (1946). Notícias sobre novas formas na Flora de Glossopteris do Brasil Meridional. Divisão de Geologia e Mineralogia: Notas Preliminares e Estudos, 34, 1-6.

Dolianiti, E. (1948). A Paleobotânica no Brasil. Divisão de Geologia e Mineralogia: Boletim do Departamento Nacional de Produção Mineral, 123, 1-87.

Dolianiti, E. (1952). La flore fossile du Gondwana au Brésil d'aprés sa position stratigraphique. 19 International Geological Congress. Symposium Series de Gondwana, 285-301. Alger.

Dolianiti, E. (1953a). A Flora do Gondwana Inferior em Santa Catarina. 1: o gênero Glossopteris. Divisão de Geologia e Mineralogia: Notas Preliminares e Estudos, 60, 1-7.

Dolianiti, E. (1953b). A Flora do Gondwana Inferior em Santa Catarina. 2: o gênero Taeniopteris. Divisão de Geologia e Mineralogia: Notas Preliminares e Estudos, 61, 1-7.
Dolianiti, E. (1953c). Considerações sobre a presença de Gondwanidium plantianum no Rio Grande do Sul. Anais da Academia Brasileira de Ciencias, 25(2), 126-132.

Dolianiti, E. (1954a). A Flora do Gondwana Inferior em Santa Catarina. 4: o gênero Vertebraria. Divisão de Geologia e Mineralogia: Notas Preliminares e Estudos, 81, 1-5.

Dolianiti, E. (1954b). Gangamopteris angustifolia e G. buriadica na Formação Maricá do Rio Grande do Sul. Divisão de Geologia e Mineralogia: Notas Preliminares e Estudos, 87, 1-6.

Dolianiti, E. (1956a). Um verticilo de Glossopteris no Gondwana do Estado de Santa Catarina. Anais da Academia Brasileira de Ciencias, 28(1), 115-118.

Dolianiti, E. (1956b). A Flora do Gondwana do Estado de Santa Catarina. 4: o gênero Sphenopteris. Divisão de Geologia e Mineralogia: Notas Preliminares e Estudos, 95, 1-8.

Dolianiti, E. (1971). A Flora do Gondwana Inferior em Santa Catarina. 7: o gênero Ottokaria, Ottokaria sanctacatarinae n. sp. Anais da Academia Brasileira de Ciencias, 43(Supl.), 337-342.

Guerra-Sommer, M. (1989). Megafloras ocorrentes em horizontes associados a carvões no Rio Grande do Sul. Acta Geológica Leopoldensia, 29(12), 93-122.

Guerra-Sommer, M., Cazzulo-Klepzig, M. (1993). Biostratigraphy of the Southern Brazilian Neo Paleozoic Gondwana Sequence: a preliminary palaeobotanical approach. Douzième International Congrés de la Stratigraphie et Géologie du Carbonifére et Permien: Comptes rendus, v. 2, 61-72. Buenos Aires.

Guerra-Sommer, M., Cazzulo-Klepzig, M., MarquesToigo, M. (1995). Gondwanostachyaceae (Equisetopsida) no Gondwana Sul-Brasileiro (Formação Rio Bonito) com mega e microflora associadas. Pesquisas em Geociências, 22(1-2), 64-73.

Guerra-Sommer, M., Cazzulo-Klepzig, M., Menegat, R., Formoso, M. L. L., Basei, M. A. S., Barboza, E. G., Simas, M. W. (2008). Geochronological data from Faxinal coal succession in the Southern Paraná Basin: a preliminary approach combining radiometric $\mathrm{U} / \mathrm{Pb}$ age and palynostratigraphy. Journal of South American Earth Sciences, 25(2), 246-256.

Guerra-Sommer, M., Marques-Toigo, M., Paim, P. S. G., Henz, G. I., Silveira, J. B. R., Backeuser, Y. (1984). Estudo microflorístico e petrológico da Mina do Faxinal, Formação Rio Bonito (Permiano), RS. Boletim IG/USP, 15, 73-83.

Holz, M., França, A. B., Souza, P. A., Iannuzzi, R., Rohn, R. (2010). A stratigraphic chart of the Late Carboniferous/ Permian succession of the eastern border of the Paraná Basin, Brazil, South America. Journal of South American Earth Sciences, 29, 381-399. 
Iannuzzi, R. (2002) Afloramento Bainha (Criciuma), SC: Flora Glossopteris do Permiano Inferior. In: Schobbenhaus, C; Campos, D.A., Queiroz, E.T; Winge, M; Berbert-Born, M.L.C. (Eds.), Sítios Geológicos e Paleontológicos do Brasil, v. 1, 23-31. Brasilia: DNPM.

Iannuzzi, R. (2010). The flora of early Permian coal measures from the Paraná Basin: a review. International Journal of Coal Geology, 83, 229-247.

Iannuzzi, R., Boardman, D. R. (2008) Novas ocorrências de Botrychiopsisplantiana (Carr.) Arch. and Arr. no afloramento Quitéria, Permiano Inferior, Rio Grande do Sul: implicações bioestratigráficas. XII Simpósio de Paleobotânicos e Palinólogos, 95. Florianópolis: UFRGS/ALPP.

Iannuzzi, R., Marques-Toigo, M., Scherer, C. M. S., Caravaca, G., Vieira, C. E. L., Pereira, L. S. (2003a). Reavaliação da fitobioestratigrafia da sequência gondvânica sul-riograndense: estudo de caso do afloramento Morro do Papaléo (Bacia do Paraná, Permiano Inferior). I Encontro Sobre Estratigrafia do Rio Grande do Sul: Escudos e Bacias, 182-185. Porto Alegre: UFRGS.

Iannuzzi, R., Marques-Toigo, M., Scherer, C. M. S., Caravaca, G., Vieira, C. E. L., Pereira, L. S. (2003b). Phytobiostratigraphical revaluation of the Southern Brazilian Gondwana sequence (Paraná Basin, Lower Permian). International Congress on Carboniferous and Permian Stratigraphy, 15, 240-242. Utrecht.

Iannuzzi, R., Scherer, C. M. S., Caravaca, G. (2007). Taphonomy and paleoecology of the southern Brazilian Glossopteris Flora (Paraná Basin, Lower Permian). Cuadernos del Museo Geominero, 8, 201-206.

Iannuzzi, R., Scherer, C. M. S., Souza, P. A., Holz, M., Caravaca, G., Adami-Rodrigues, K., Tybusch, G. P., Souza, J. M., Smaniotto, L. P., Fischer, T. V., Silveira, A. S., Lykawka, R., Boardman, D. R., Barboza, E. G. (2009). Afloramento Morro do Papaléo, Mariana Pimentel, RS-Registro ímpar da sucessão sedimentar e florística pós-glacial do Paleozóico da Bacia do Paraná. In: M. Winge, C. Schobbenhaus, C. R. G. Souza, A. C. S. Fernandes, E. T. Queiroz, M. Berbert-Born, Campos, D. A. (Eds.), Sitios Geológicos e Paleontológicos do Brasil, v. 2, 321-336. Brasília: DNPM/CPRM. <http:// www.unb.br/ig/sigep/sitio101/sitio101.pdf>.

Jasper, A., Menegat, R., Guerra-Sommer, M., CazzuloKlepzig, M., Souza, P. A. (2006). Depositional cyclicity and paleoecological variability in Quiteria outcrop. Rio Bonito Formation, Paraná Basin, Brazil. Journal of South American Earth Sciences, 21(3-4), 276-293.

Jasper, A., Ricardi-Branco, F., Guerra-Sommer, M. (2005). Coricladus quiteriensis gen. et. sp. nov., a new conifer in Southern Brazil Gondwana (Lower Permian, Paraná Basin). Anais da Academia Brasileira de Ciencias, 77(1), 157-168.
Krebs, A. S. J. (2004). Contribuição ao conhecimento dos recursos hidricos subterrâneos da área correspondente à bacia hidrográfica do Rio Araranguá, SC, 2 v. Tese (Doutorado). Florianópolis: Universidade Federal de Santa Catarina.

Lejal-Nicol, A., Bernardes-de-Oliveira, M. E. C. (1979). Sur une nouvelle espèce de Cyclodendron Kräusel, 1928 du Permien Inférieur de l'etat de Santa Catarina au Brèsil. 104 Congrès National des Societés Savantes, Sciences, fasc. I, 121-132. Bordeaux.

Machado, E. R. (1972). O carvão Neopaleozóico do Brasil Meridional. Simpósio Internacional sobre os sistemas Carbonífero e Permiano na América do Sul. Anais da Academia Brasileira de Ciencias, 44(supl.), 209-235.

Medeiros, R. A., Thomaz Filho, A. (1973). Fácies e ambientes deposicionais da Formação Rio Bonito. Anais do XXVII Congresso Brasileiro de Geologia, v. 3, 3-12. Aracaju: SBG.

Mendes, J. C. (1963). Novos aspectos da estratigrafia das camadas eogondvânicas da Bacia do Paraná. Engenharia, Mineração e Metalurgia, 38(226), 189-192.

Mendonça Filho, J. G., Guerra-Sommer, M., Klepzig, M. C., Mendonça, J. O., Silva, T. F., Kern, M. L., Menezes, T. R., Jasper, A., Silva, M. C., Santos, L. G. C. (2013). Permian carbonaceous rocks from the Bonito Coalfield, Santa Catarina, Brazil: organic facies approaches. International Journal of Coal Geology, 111, 23-36.

Milani, E. J., Faccini, U. F., Scherer, C. M. S., Araújo, L. M., Cupertino, J. A. (1998). Sequences and stratigraphic hierarchy of the Paraná Basin (Ordovician to Cretaceous), Southern Brazil. Boletim IG-USP. Série Cientifica, 29, 125-173.

Millan, J. H. (1965). Considerações sobre as sementes do Carbonífero do Brasil. Divisão de Geologia e Mineralogia: Notas Preliminares e Estudos, 123, 1-8.

Millan, J. H. (1967a). O gênero Samaropsis na Flora do Gondwana do Brasil e de outros países. Boletim do Museu Nacional: Geologia, 32(3), 1-12.

Millan, J. H. (1967b). Novas frutificações na Flora de Glossopteris do Gondwana Inferior do Brasil. Dolianitia gen. nov. Divisão de Geologia e Mineralogia: Notas Preliminares e Estudos, 140, 1-19.

Millan, J. H. (1969a). The Gymnospermic and Platyspermic seeds of the Glossopteris Flora from Brazil and correlated foreign regions. I Symposium on Gondwana Stratigraphy, v. 2, 107-122. Buenos Aires: IUGS.

Millan, J. H. (1969b). Sobre Plumsteadiella um novo vegetal comum ao Gondwana inferior do Brasil e da África do Sul. Plumsteadiella apedicellata sp. nov. Boletim do Museu Nacional: Geologia, 34, 1-8.

Millan, J. H. (1971). Ocorrências de folhas de Noeggerathiopsis presas a um eixo caulinar, no Gondwana do Estado de 
Santa Catarina. Anais da Academia Brasileira de Ciencias, 43(supl.), 343-350.

Mussa, D. (1958). Conífera fóssil do Carbonífero Superior de Santa Catarina. Boletim do Departamento Nacional de Produção Mineral, Divisão de Geologia e Mineralogia, 182, 1-23.

Northfleet, A. A., Medeiros, R. A. E., Muhlmann, H. (1969). Reavaliação dos dados geológicos da Bacia do Paraná. Boletim Técnico da Petrobrás, 12(3), 291-343.

Piccoli, A. E. M., Menegat, R., Guerra-Sommer, M., MarquesToigo, M., Porcher, C. C. (1991). Faciologia da seqüência sedimentar nas folhas de Quitéria e Várzea do Capivarita, Rio Grande do Sul. Pesquisas, 18(1), 31-43.

Putzer, H. (1952). Camadas de carvão mineral e seu comportamento no sul de Santa Catarina. Boletim do Departamento Nacional de Produção Mineral, Divisão de Geologia e Mineralogia, 91, 1-182.

Read, C. B. (1941). Plantas fósseis do Neopaleozóico do Paraná e Santa Catarina, XII, 102 p. Monografias da Divisão de Geologia e Mineralogia.

Ricardi-Branco, F. S. (1998). Tafoflora gondvânica do Membro Triunfo Formação Rio Bonito (Eopermiano), no Municipio de Figueira, PR. Tese (Doutorado). São Paulo: Instituto Geociências - USP.

Ricardi-Branco, F., Rösler, O. (2004). The paleoflora of Figueira in the context of the Neopaleozoic of the Paraná Basin, Brazil. Terrae, 1(1), 44-51.

Rigby, J. F. (1969). (Rhodea) criciumana sp. nov.: a new plant from the Tubarão Group of Brazil. Boletim Paranaense de Geociências, 27, 111-122.

Rigby, J. F. (1972a). The upper Paleozoic Flora at Lauro Müller, Santa Catarina, Southern Brazil. Anais da Academia Brasileira de Ciencias, 44(suppl.), 279-293.

Rigby, J. F. (1972b). The Notocalamitaceae: a new family of upper Paleozoic Equisetaleans. The Palaeobotanist, 19(2), 161-163.

Rigby, J. F. (1972c). On Arberia White and some related Lower Gondwana female frutifications. Palaeontology, 15(1), 108-120.

Rösler, O. (1972). Flora da Formação Rio Bonito no Estado do Paraná. Tese (Doutorado). São Paulo: Instituto de Geociências - USP.

Rösler, O. (1973). Tafofloras Neopaleozóicas da Bacia do Paraná. II Congresso Latinoamericano de Geologia, 32. Caracas.

Rösler, O. (1975). Confronto de aspectos entre as tafofloras neopaleozóicas do Brasil e Argentina. Actas del Primer Congreso Argentino de Paleontologia e Bioestratigrafia, 505-523. Tucumán: APA.
Rösler, O. (1979). Plantas Fósseis de São João do Triunfo (PR), Formação Rio Bonito, e suas implicações geológicas. II Simpósio Regional de Geologia, v. 1, 181-194. Rio Claro: SBG.

Schneider, R. L., Muhlmann, H., Tommasi, E., Medeiros, R. A., Daemon, R. F., Nogueira, A. A. (1974). Revisão estratigráfica da Bacia do Paraná. XXVIII Congresso Brasileiro de Geologia, 41-65. Porto Alegre: SBG.

Simas, M. W., Guerra-Sommer, M., Cazzulo-Klepzig, M., Menegat, R., Santos, J. O. S., Ferreira, J. A. F., DeganiSchmidt, I. (2012). Geochronological correlation of the main coal interval in Brazilian Lower Permian: radiometric dating of tonstein and calibration of biostratigraphic framework. Journal of South American Earth Sciences, 39, 1-15.

Simas, M. W., Guerra-Sommer, M., Mendonça Filho, J. G., Cazzulo-Klepzig, M., Formoso, M. L. L., Degani-Schmidt, I. (2013). An accurate record of volcanic ash fall deposition as characterized by dispersed organic matter in a lower Permian tonstein layer (Faxinal Coalfield, Paraná Basin, Brazil). Geologica Acta, 11, 45-57.

Souza, P. A., Marques-Toigo, M. (2003). An overview on the palynostratigraphy of the Upper Paleozoic strata of the Brazilian Paraná Basin. Revista Museo Argentino Ciencias Naturales, 5(2), 205-214.

Tybusch, G. P., Iannuzzi, R. (2008). Reavaliação taxonômica dos gêneros Gangamopteris e Rubidgea, Permiano Inferior da Bacia do Paraná, Brasil. Revista Brasileira de Paleontologia, 11, 59-68.

Vieira, C. E. L., Iannuzzi, R. (2000). Presença de Pecopteris e Asterotheca no afloramento Morro do Papaléo, município de Mariana Pimentel, RS (Formação Rio Bonito, Eopermiano da Bacia do Paraná). Pesquisas, 27, 49-64.

White, D. A. (1908a). Fossil flora of the Coal Measures of Brazil. In: I. C. White (Ed.), Final report: part III, 337-617. Rio de Janeiro: Comissão de Estudos das Minas de Carvão de Pedra do Brasil.

White, I. C. (1908b). Final Report: report on the coal measures and associated rocks of South Brazil: part I, 1-300. Rio de Janeiro: Comissão de Estudos das Minas de Carvão Pedra do Brasil.

Yoshida, R. (1966). Nota sobre um tufo de Glossopteridae na Camada Irapuá, Criciúma, SC. Boletim da Sociedade Brasileira de Geologia, 15(4), 69-77.

Yoshida, R. (1968). Descrição preliminar de coniferas neopaleozóicas da Bacia do Paraná. Dissertação (Mestrado). São Paulo: Faculdade de Filosofia, Ciências e Letras - USP. 